\title{
Maternity Leave and Children's Cognitive and Behavioral Development
}

December 2010

Michael Baker, baker@,chass.utoronto.ca, University of Toronto and NBER

Kevin Milligan, kevin.milligan@ubc.ca, University of British Columbia and NBER

Abstract: We investigate the impact of maternity leave on the cognitive and behavioral development of children at ages 4 and 5. The impact is identified by legislated increases in the duration of maternity leave in Canada, which significantly increased the amount of maternal care children received in their first year, and how long they were breastfed. We carefully document that other observable inputs to child development do not vary across cohorts of children exposed to different maternity leave regimes. Our results indicate that these changes had no positive effect on indices of children's cognitive and behavioral development measured just prior to school entry.

We have benefited from comments from seminar participants at UC Davis, Laval, Manitoba, Stavanger, Texas and Waterloo. We gratefully acknowledge the research support of SSHRC (Baker Grant, \#410-2008-0346, Milligan Grant \#410-2006-0928). We thank the staffs of the Toronto and B.C. Research Data Centres for their technical support. This paper represents the views of the authors and does not necessarily reflect the views of Statistics Canada 
Maternity leave has emerged as the public policy of choice in many countries for improving the lives of mothers and infants after childbirth. Most recently Australia announced a paid maternity leave scheme starting in 2011, leaving the United States as the only OECD country without a statutory, paid leave program for women giving birth. In most cases, child development forms part of the legislative basis for these policies. The American Family and Medical leave Act states “...it is important for the development of children and the family unit that fathers and mothers be able to participate in early childrearing...". ${ }^{1}$ The Australian initiative aims to provide " ...babies the best start in life. The payment will enable more parents to stay at home to care for their baby full-time during the vital early months of social, cognitive and physical development" (Commonwealth of Australia 2009). A recent extension of paid maternity leave in the United Kingdom seeks to "...give children the best start in life..." as the “...evidence confirms the value of consistent one-to-one care in the first year of a child's life." (Employment Relations Directorate 2006, p. 2).

These statements about the impact of maternity leave are primarily based on indirect evidence. There simply aren't many studies of the impact of maternity leave on child development. Instead legislative initiatives draw on evidence of the impact of maternal employment or non-parental care on child development projected onto the maternity leave statute. There are a number of reasons to wonder if this projection is appropriate.

First, universal leave statutes typically affect a different and larger group of children than the groups studied in these other literatures. For example, studies that exploit instruments for maternal employment, such as welfare reform, tell us something about its impact on the children of mothers who respond to the "treatment". Some of the best, experimental evidence on the

\footnotetext{
${ }^{1} \mathrm{http} / / /$ www.dol.gov/esa/whd/fmla/fmlaAmended.htm\#SEC_2_FINDINGS_AND_PURPOSES
} 
impact of non-parental care is for children "at risk". Unless we can assume homogeneous response within the population, it is not clear this evidence can predict the average impact of a maternity leave law.

Second, maternity leaves may affect maternal employment or the use of non-parental care in a different way than the treatments in other literatures. The variation in maternal employment induced by a maternity leave is typically transitory, as the affected mothers will eventually return to work, often within a year of birth. For instruments in other literatures the variation in employment or care may be permanent or more persistent.

Third, maternity leaves can affect other inputs, in addition to maternal care, that may have separate effects on child development. For example there is evidence that maternity leaves affect the length of time babies are breastfed (e.g., Baker and Milligan 2008a).

Finally, whether paid or not, maternity leave policies can affect family income. If maternal care is not a perfect substitute for monetary resources, it would be important to consider whether the identifying variation in these other literatures involved comparable impacts on family resources.

These arguments suggest that for the sake of good policy-making, it's important to obtain more evidence on the direct impact of maternity leave policy. This is exactly what we offer in this paper. We examine the impact of an expansion of the Canadian paid maternity leave programs on measures of children's cognitive and behavioral development at ages 4 and 5 years. At the end of 2000, Canadian laws were passed that expanded the duration of job-protected, partially compensated maternity/parental leave from approximately 6 months to a full year. Previous research indicates that these changes increased the duration of maternal care children received in the first year of life with an offsetting reduction in unlicensed non-parental care and 
maternal full time work (Baker and Milligan 2010, Hanratty and Trzcinski 2009). Our evidence therefore speaks to the impact of changes in maternal employment and non-parental care precisely within the context of a maternity leave policy, rather than indirectly as in much of the previous evidence.

Beyond providing direct, credible evidence on the impact of this particular reform, our results have relevance more broadly. Specifically, four specific features of our analysis enhance its relevance. First, the extension of leave from 26 to 52 weeks is informative for the many OECD countries that currently have short (i.e., 12-39 weeks) maternity leave entitlements (see Ray 2008). Second, the age-range we examine is the one in which previous evidence suggests that the cognitive impact of early maternal care manifests; an age that matters critically for evaluation of development. Third, the income replacement, provided through the Canadian Employment Insurance System, is relatively modest. It is comparable to the benefits provided in many jurisdictions including Australia (proposed), the United Kingdom, as well as the paid leave programs in California, New Jersey, Washington and states that provide maternity benefits through Temporary Disability Insurance programs (see Brustenev and Vroman 2007). Finally, our primary measure of cognitive development, the Peabody Picture Vocabulary Test (PPVT), is the workhorse of research on the impacts of maternal employment. Because so much research has used this same measure, we can compare our results directly to the existing research that is cited as a rationale for maternity leave reforms. Combined, these factors mean that we can study children at an interesting age using a standard evaluation instrument for a reform that spans the experience of many countries.

Our analysis makes use of the National Longitudinal Survey of Children and Youth (NLCY). This is a nationally representative survey of Canadian children that provides an array 
of developmental indicators. We focus on cognitive markers-PPVT, Know Your Numbers, Who Am I? - and four behavioral indices. Our analysis compares children in birth cohorts on either side of the leave reform. There are good reasons to believe that these children received the same developmental inputs over their first 5 years, with the important exception of those inputs directly affected by the change in leave law. We attempt to validate this hypothesis by documenting any differences in observable inputs across the cohorts at different ages.

We find that the expansion of parental leave - and the resulting extra time spent with parents in the first year of a child's life—-had no positive impact on indices of children's cognitive and behavioral development, this despite the fact it had substantial impacts on the maternal care and non-licensed non-parental care children received in their first year, as well as how long they were breastfed.

\section{Previous Literature}

As noted in the introduction there are relatively few direct evaluations of the impact of maternity/parental leaves on children's outcomes. Baker and Milligan (2010) examine the effect of the same policy reform analyzed here on behavior, parental inputs and a measure of motor and social development at ages up to 24 months. They find little evidence of an impact at those ages. The present study is distinguished by looking at indicators of cognitive development which were not observable in the data at the younger ages in the previous study. Moreover, some previous evidence suggests that the impact of early maternal employment/childcare does not manifest

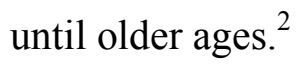

\footnotetext{
${ }^{2}$ For example, Brooks-Gunn et al. (2002) find that the cognitive impact of maternal employment in the children's first year of life manifest by 36 months but not at earlier ages.
} 
Most other studies examine the longer term impacts of maternity leave. Dustmann and Schonberg (2008) look at the impacts of changes to Germany's paid leave program. They find little evidence that expansion of leave in this country affected children's selective high school attendance or grade progression. Rasmussen (2009) examines changes of the leave law in Denmark. She finds no impact on children's high school enrollment and completion, or on grade point average. Liu and Skans (2009) investigate an extension of parental benefits in Sweden. They find no average impact on children's test scores and grades at age 16, although there is a positive effect for the children of well educated mothers.

In contrast, Carneiro et al. (2008) find an extension of job protected leave in Norway from 12 to 18 months, which increased the duration of leave actually taken by two months, did have positive impacts on children's educational attainment. Increases in college attendance, years of completed education and IQ are reported, as well as reductions in high school dropout and teenage pregnancies.

The present analysis complements this research by providing an important bridge between studies of the early and long-run impacts of parental leave. For example, evidence that parental leave has no long-run impact might result from an early effect that is offset by subsequent compensating behavior by parents or accommodation by schools. By carefully documenting the observable inputs to child development up to age 6 , and studying the cognitive impact of maternity leave at the age of school entry, our analysis addresses this gap in the record. 


\section{The Reform}

Our analysis is based on a reform of Canadian maternity/parental leave (henceforth maternity leave) laws at the end of $2000 .^{3}$ Job protected, uncompensated, maternity leave is provided by provincial labor standards law, and historically there has been some variation in its duration across provinces. ${ }^{4}$ In contrast, income replacement during the leave is provided through the federal Employment Insurance (EI) system and there is one standard for the country. ${ }^{5}$

On December 31, 2000, the duration of income replacement in the EI system was raised from 25 weeks to 50 weeks, each subject to a 2 week waiting period in which no benefits are received. ${ }^{6}$ The legislation enacting the changes was introduced to Parliament on April 7, 2000, and received Royal Assent on June 29, 2000. In the next six months before the EI reform became effective most provinces announced increases in the duration of job-protected leave to $52+$ weeks to commence coincidently with the change in the EI law. ${ }^{7}$ In many instances the change was not announced or enacted until November or December $2000 .^{8}$ By June 2001, all

\footnotetext{
${ }^{3}$ Many of the details are reported in Baker and Milligan (2008a).

${ }^{4}$ Prior to the reform the duration of unpaid job protected leave varied from 18 weeks to 70 weeks, with the majority of provinces offering 29-36 weeks.

${ }^{5}$ An initial 15 weeks of benefits is reserved for the mother. Subsequent weeks can be taken by either the mother or the father. Historically, mothers have taken the vast majority of the leave, although this is (slowly) changing in recent years. Marshall (2008) reports that in 200623 percent of eligible fathers took some parental leave. This average reflects incidence of 56 percent in Quebec (where there is dedicated leave for fathers) and 11 percent in the rest the country. As documented below, observations from Quebec are deleted from our analysis sample. ${ }^{6}$ In each case the period of maternity leave benefits, reserved for the mother, is 15 weeks. The number of parental leave benefits available to either the mother or father was increased from 10 to 35 weeks.

${ }^{7}$ The changes in provincial mandates were from 29-35 weeks to 52-54 weeks with the exceptions of Alberta, where the change was from 18 weeks to 52 weeks, and Quebec, where the entitlement did not change from a level of 70 weeks.

${ }^{8}$ For example, as late as October 2000 Ontario did not appear on track to make the change but did eventually in December due to public outcry.
} 
provinces offered job protection of sufficient duration to accommodate the new 50 week EI standard. ${ }^{9}$

\section{The Impact of the reform}

As explained in the introduction, the reform we analyze led to an increase in the maternal care children received in their first year of life. Baker and Milligan (2008a) show this care increased by over 3 months for those affected by the reform, a 50 percent increase over the prereform mean. There was a contemporaneous large decrease in mothers' full time employment of 59 percent (Baker and Milligan 2010). Also the proportion of children in non-parental care fell by 44 percent, almost all of which came out of unlicensed care outside the home. Finally, for those affected by the reform, there was a one month increase in the amount of time children were breastfed — one-half month in exclusive breastfeeding (Baker and Milligan 2008a).

We consider the impacts of these changes within the context of a development production function.

$$
D_{i}=M_{i} \beta_{1}+C_{i} \beta_{2}+B_{i} \beta_{3}+X_{i} \beta_{4}+A_{i} \beta_{5}+\varepsilon_{i},
$$

where $D$ is the developmental outcome, $M$ is maternal care, $C$ is other (non-parental) care, $B$ is breastfeeding, $X$ are other inputs, $A$ is innate ability and $\varepsilon$ for the current purposes is any fundamentally unobservable components of $M, C, B, X$ and $A$ as well as other determinants of $D$. In application some or all of the $M, C, B, X$ and $A$ could be actually unobserved and so would be part of $\varepsilon$ as well as measurement error in $D$. Note for some children $M=(24-C)$. The maternity leave reform we analyze has been shown to increase $M$ and $B$ and decrease $C$.

\footnotetext{
${ }^{9}$ Two provinces, Saskatchewan and Alberta, did not change their job protected leave standards until 2001. Unfortunately there are not sufficient observations from these provinces over the 2-6 months of delay to take advantage of this feature of the reform.
} 
$M$ and $C$ capture the time inputs to children's development, which can provide stimulation, instruction and nurturing. There is an important quality dimension here that the maternal/non-parental distinction may capture, but not in the same way for all families and/or at all ages. Ultimately, therefore, while we might expect development to be increasing in the time commitment of both mothers and caregivers, the relative impact of $M$ and $C$ is an empirical question.

There are a number of possibilities as a mechanism for the impact of $B$. One is the constitution of breast milk that is not perfectly replicated in formula. Components missing from formula may be important for child development. Another is an epigenetic effect that comes through the emotional and physical bonding breastfeeding facilitates. A final channel is that breastfeeding simultaneously enables other interactions between mother and child that promote development. This latter effect might be viewed simply as an increase in $M$.

We can look to evidence from other literatures for the sign of the parameters $\beta_{1}, \beta_{2}$ and $\beta_{3}$. Evidence of the impact of maternal care comes primarily from research on maternal employment rather than on the time input mothers actually provide to their children. We are particularly interested in evidence on variation in $M$ in the first year of life. For example, BrooksGunn et al. (2002) report that full-time maternal employment in the year of life has negative cognitive effects that manifest by 3 years of age, although not at earlier ages. ${ }^{10}$ The effect is strongest —over one fifth of a standard deviation — for the return to work at the $9^{\text {th }}$ month after birth. Ruhm (2004) reports reductions in PPVT scores of 7-8 percent of a standard deviation from maternal employment in the first year, with the largest effects from full time employment. James-Burdumy (2005) and Hill et al. (2005) find maternal employment in the first year has

${ }^{10}$ The measure of development is the Bracken School Readiness Scales. 
smaller negative effects on math and reading scores measured at ages 5-18. ${ }^{11}$ Finally, Bernal (2008) reports that a full year of full-time maternal employment in the first five years of life reduces test scores by 0.13 of standard deviation. ${ }^{12}$ Waldfogel (2006) in her review of the literature concludes "...children whose mothers work in the first year of life, particularly if they work full time, do tend to have lower cognitive test scores at age three and thereafter." (p. 55)

Much of the evidence on the impact of non-parental care on cognitive development focuses on older children and the preparation for entrance into kindergarten and grade one. O’Brien Caughy et al. (1994) report that entrance into daycare before the first birthday was associated with higher test scores for lower income children and lower test scores for higher income children. ${ }^{13}$ For the U.K. Greg et al. (2005) find that children who receive informal care from friends and relatives in the first 18 months of life combined with full time maternal employment have lower cognitive outcomes. In the Canadian context, Lefebvre et al. (2008) report that Quebec's universal, low fee childcare program, which serves children from birth, is related to reductions in PPVT scores of just under one-third of a standard deviation.

There is also research relating non-parental care to behavioral development. Loeb et al. (2007) find particularly disadvantageous effects from entry into non-parental center based care before the age of one. Magnuson et al. (2007), Baker et al. (2008), and the research summarized in Belsky (2006) provide further evidence that non-parental care can lead to problem behavior.

The impact of breastfeeding on cognitive development is generally thought to be positive, however, the evidence is mostly observational and a meta analyses has disputed this claim (Der, Batty, and Deary 2006). Recently Kramer et al. (2008b) have revisited this issue offering

\footnotetext{
${ }^{11}$ The scores in these studies are from the PPVT and the Peabody Individual Achievement Tests.

${ }^{12}$ The scores are from the PPVT and the Peabody Individual Achievement Tests.

${ }^{13}$ The scores are from the Peabody Individual Achievement Tests.
} 
experimental evidence of the effect based on a controlled experiment in Belarus; the PROBIT study reported in Kramer et al. (2001). They report that the increase in breastfeeding induced in the PROBIT study is related to an increase in cognitive development measured at 6.5 years of age of just over one-third of a standard deviation. The evidence for verbal skills is the strongest.

Evidence of an impact of breastfeeding on behavior is relatively scarce. Scattered studies report some negative effects of either not being breastfed or being weaned early, ${ }^{14}$ but again these are observational results. Kramer et al. (2008a) examines the impact of breastfeeding on children's behavior at 6.5 years of age in the same experimental design, finding no effect.

Summing up, the prediction for the impacts on child development for a reform of the magnitude considered in this paper from other literatures is unambiguously positive. The increase in $M$ and corresponding decrease in $C$ at ages less than one should improve both cognitive development and behavior. An increase in $B$ would increase cognitive development but have little effect on behavior. These predictions are enhanced by the facts that the reform we study decreased mothers' full time employment and the amount of unlicensed care by a nonrelative that children received. However, these predictions from other literatures are only relevant if maternity leaves have comparable impacts on care and breastfeeding for similar populations. This is the empirical question we pursue here.

Bernal and Keane (2009) note that few empirical investigations of equation (1) can control for differences in $X$ across children. Also, most studies consider only current inputs and ignore any cumulative effect of past inputs. To some extent this is because measures of $X$ and/or past inputs are not available in most data sets. One of the strengths of our study is that under our identifying assumptions there should not be any differences in $X$ or past inputs across birth

${ }^{14}$ See discussion in Kramer et al. (2008a). 
cohorts, other than those induced by the difference in maternity leave regimes they experienced. Furthermore, we can empirically investigate the inter-birth cohort differences in measurable inputs at earlier ages to test the validity of this assumption.

\section{The Data}

The NLSCY is a nationally representative survey of Canada's children. The data we use is a cross section of children up to 5 years of age that is available biannually starting in $1994 / 5$. There are approximately 2,000 children of each age in each wave. The 2006/07 data are currently the latest available.

The survey offers three measures of the cognitive development of children aged 4-6. Each of these measures is based on research and is comparable to measures used in other studies. The first measure is the Peabody Picture Vocabulary Test-revised (PPVT-R), which has been used extensively in previous studies of child development and is well known in the literature.

The second is the Number Knowledge Test, which was developed by a team led by Robbie Case at the Ontario Institute for Studies in Education (Case et al. 1996). The test consists of 30 questions that are used to rank children on a four point scale. It assesses children's understanding of the system of whole numbers, probing their ability to count by rote, quantify small sets of objects, their knowledge of number sequence and their ability to solve simple arithmetic problems. The questions and answers are delivered orally, and no aids (e.g., pencil and paper) are allowed. The four point ranking is available for each cohort. The ranking are: 0 - the child has not reached the predimensional level, 1 - the child has reached the predimensional level (4 year old equivalent), 2 - the child has reached the unidimensional level (6 year old equivalent) and 3-the child has reached the bidimensional level (8 year old 
equivalent). Unfortunately the raw and standardized scores on the 30 questions are only available for the later birth cohorts.

The third is the "Who am I?" measure, a test developed by a team led by Molly de Lemos at the Australian Council for Educational Research (de Lemos and Doig, 1999). It consists of copying and writing tasks that help reveal children's understanding and use of symbols. The assessment is intended to distinguish between specific learning (how to write one's own name) and more advanced conceptualization. The test consists of 10 questions that are each awarded scores between 1 and 4 . The overall or total score on the instrument is simply the sum of the scores on the individual questions and therefore ranges in principle between 10 and 40.

We also investigate a number of behavioral indices. These are parent-reported measures based on best practices. ${ }^{15}$ They measure, respectively, hyperactivity, anxiety, physical aggression and indirect aggression. Each is built up from a series of questions about the children's reactions to other people and different situations. Parent-reported indices are not without their critics. The online appendix to Baker et al. (2008) provides a detailed discussion of these measures.

We select children aged 4 and 5 born in the years 1998-2002. These birth years bracket the changes to the maternity leave laws, yielding three pre-reform cohorts and two post-reform cohorts. Our objective here is to choose cohorts that are temporally adjacent to the reform to

${ }^{15}$ The measures are based on questions drawn from the Ontario Child Health Study, the Montreal Longitudinal Survey, and the Child Behavior Checklist of T. M. Achenbach. The Ontario Child Health Survey questions are based on items in the Child Behavior Checklist (Achenbach and Edelbrock 1983), modified so that that the symptoms canvassed correspond to the classification of psychiatric disorders in DSM - III - R (the Diagnostic and Statistical Manual of Mental Disorders of the American Psychiatric Association) (Boyle et al. 1993). The questions in the Montreal Longitudinal Survey are based on the Social Behavior Questionnaire. This includes 28 items from the Preschool Behavior Questionnaire (Behar and Stringfield 1974; Tremblay et al. 1987), an adaptation of the Children's Behavior Questionnaire (Rutter 1967) and the Prosocial Behavior Questionnaire (Weir, Stevenson, and Graham 1980; Weir and Duveen 1981). 
control as much as possible for unobserved time effects. The 2002 birth cohort is the latest for which we have cognitive scores.

We omit all observations from Quebec, to account for the fact that this province's universal, low fee child care program was extended to children under the age of two in the fall of 2000, and so its effect might be easily confused with the effects of change in maternity leave laws. We also omit children who live in single parent households because concurrent changes in Canada's system of child tax benefits, which disproportionately benefited these families, might confound the inference. Therefore, our results are for children in two parent/adult households, who are the majority beneficiaries of universal maternity leave policies. ${ }^{16}$

We also use data from the Labour Force Survey (LFS) for part of the analysis. The primary purpose of this monthly survey is to collect information on the labor force status of Canadians. We make use of the data on labor force status, as well as questions on reasons for not actively seeking work and on weekly and hourly earnings. We again exclude observations from the province of Quebec and from single-parent households.

Age is recorded in the LFS, but exact date of birth is not available. By sampling from either the December or January surveys we can identify year of birth with a relatively small amount of error for single year categories. ${ }^{17}$ The reference week for the monthly survey is the week containing the $15^{\text {th }}$ day. As an example, we designate children aged 4 from the January survey as part of the birth cohort 5 years before the survey year. The coding will miss those born

\footnotetext{
${ }^{16}$ Alberta and Saskatchewan did not change their maternity leave provisions to match the change in the federal EI rules until after December 2000. We therefore also exclude the very small number of children born in Alberta and Saskatchewan in the months between December 2000 and the point when the provincial maternity leave mandate changed a few months later. ${ }^{17}$ January and December are the trough of the seasonal birth cycle in Canada. Compared to the U.S. the peak in monthly births in Canada occurs earlier than in the U.S., and the relative distance between peak and trough is greater. See He and Earn (2007).
} 
in the first two weeks of the preceding year, and miscode those born in the two weeks preceding the reference week. Likewise in the December survey denoting children aged 4 to belong to the birth cohort born 4 years before the survey year misses those born in the two weeks following the survey and miscodes those born in the last two weeks of the preceding December. Any impact of this error is attenuated by the fact that our ultimate objective is to divide the cohorts by whether they faced the new maternity leave regime. However, the miscoding between the 2000 and 2001 birth cohorts means that some children will erroneously be designated as "treated" and vice versa. We report results using the January sample, but the results are very similar using the December samples.

Single year age categories are available for ages 0,3,4 and 5. Ages 1 and 2, however, are grouped together. As a result in the December 2000 or January 2001 surveys, those aged 2 will have been exposed to the original leave regime while those aged 1 will have been born during the reform period. To address this problem we do not sample from the December 2000 or January 2001 surveys for this age group. To ensure that there are two post reform observations for these ages, we substitute the December 2002 or January 2003 surveys.

\section{Empirical Framework}

Our primary empirical approach uses a two-stage estimator that captures differences across year of birth cohorts. We supplement this approach with a regression discontinuity analysis.

Our two-stage approach takes the following form. We first estimate the equation

$$
y_{i}=X_{i} \beta+\sum_{t} \gamma^{t} Y O B t_{i}+u_{i},
$$


where $y$ is the outcome of interest for child i, $X$ are conditioning variables, YOB denotes year of birth and the equation is estimated without a constant. ${ }^{18}$ Our focus here is on the $\gamma^{t}, t \in\{1998,2000, \ldots, 2002\}$, year of birth specific effects for the conditional mean. We look for the estimates of these effects to display a specific pattern relative to the timing of the maternity leave reforms. For example, Baker and Milligan (2010) show that when the dependent variable is the number of months the mother is at home in the child's first year of life the estimates display a sharp increase starting with the 2001 birth cohort (the first "treated" year of birth), which is not evident in any other comparison of the effects for adjacent birth cohorts. It is the check for this pattern that allows us to interpret our second stage summary equation

$$
\gamma^{t}=\alpha+\phi \mathrm{POST}_{t}+\varepsilon_{t}
$$

where POST equals 1 for cohorts born after the reform (years 2001 and 2002). Estimation of this second equation is based on 5 observations.

Some of the possible biases to the estimation of the $\gamma^{t}$, and thus POST, have already been discussed. The central concern in the literature is differences in unobservables across families who make different choices about maternity leave. Here this would manifest as differences in unobservables across birth cohorts correlated with their different use of leave. By isolating the variation across birth cohorts induced by the change in legislation, we expect this type of bias to be minimal. Another source of bias is other changes in the environment that effect children's outcomes, are correlated with the $Y O B$ effects, and are not captured in $X$. This is exactly the reason we omit observations from Quebec and single-parent households from the analysis. Finally, there are the impacts of past inputs to child development that again are correlated with

${ }^{18}$ The control variables $(X)$ include dummy variables for male children, single month of child's age, province, city size, mothers' and fathers' education (4 categories), age (6 categories) and immigrant status, and the presence of up to 2 older or younger siblings. The regressions for age standardized PPVT scores omit the single month of child's age. 
$Y O B$ and not captured in $X$. Given the structure of the analysis we expect this to be a minor source of bias, and explicitly investigate differences in observable inputs at younger ages across the birth cohorts in the course of the analysis.

In making these statements we note that as shown in Baker and Milligan (2008a) there is little difference in observables across birth cohorts, as the $X$ variables make little difference to the results. Also, we interpret POST as an estimate of the impact of the change in the leave policy only in cases where the underlying pattern in the $\gamma^{t}$, which are reported in the appendix, support this interpretation. Accordingly, our discussion of the results below makes constant reference to the patterns in the year of birth effects $\gamma^{t}$.

The use of equation (3) to estimate the impact of the reform pays heed to the advice of Donald and Lang (2007) to explicitly account for the finiteness of the variation that identifies the main effect of interest. In the current context the variation is across 5 birth cohorts. The estimation of (3) is based on 5 observations — one for each birth cohort—and has three degrees of freedom. Therefore the critical values for tests of significance are 3.18 at the five percent level and 2.35 at the 10 percent level.

In the regression discontinuity approach, we look for a change in the outcome of interest at the point where the forcing variable makes a discontinuous jump. The forcing variable here is time, with the discontinuity set at the end of December $2000 .{ }^{19}$ At the individual level, this takes the form

$$
y_{i t}=\beta_{0}+\beta_{1} P O S T_{i t}+\delta(t)+X_{i t} \beta_{2}+\varepsilon_{i t},
$$

\footnotetext{
${ }^{19}$ We impose the same sample restrictions as in our two-stage approach above, but with the additional restriction of taking out births occurring within two weeks on either side of December 31,2000 . We do this to ensure that the potential of endogenous birth timing around the point of discontinuity does not affect our results.
} 
where $\delta(t)$ is a polynomial in time intended to capture any underlying time trend. Because we do not have large samples near the point of policy change, we aggregate up to the quarter of birth for both our graphs and regression results. The regression using quarter-of-birth data are of the form

$$
\overline{y_{q}}=\beta_{0}+\beta_{1} P O S T_{q}+\delta(q)+\varepsilon_{q},
$$

where $\overline{y_{q}}$ is the average over all children born in birth quarter $q$. For these regressions, we weight the data by the inverse of the variance of the quarter of birth cell data.

\section{Results}

We begin by investigating the impact of the reform on observable inputs to child development across birth cohorts. We then proceed to the analysis of cognitive development measures, followed by behavioral scores. Given data currently available, we can examine children between ages 13 and 71 months. ${ }^{20}$ For many results, we break the sample into three age groups: 13-24 months, 25-39 months, and 48-71 months.

The most important parental input that might change with the enhanced leave eligibility is the amount of time the mother spends with her infant after birth. In figure 1 we graph the number of months in the first year after the child's birth that the mother was at home with the child. The data are reported at the quarter of birth level--points plotted are proportional to the inverse of the variance for each cell--as reported retrospectively for the age 48-71 month age group. There is a clear increase in the time spent at home after the reform. The average goes

\footnotetext{
${ }^{20}$ Baker and Milligan (2010) provide a thorough characterization of the substantial changes in maternal inputs at ages up to 12 months.
} 
from 8.2 months to 10.3 months at home. The regression discontinuity estimate using these quarterly data is $2.271(0.261){ }^{21}$

Because not all births are to women who took time off work, the graph include data for women who were either ineligible or chose not to take up any leave. If we are interested in the impact on those who took leave, we can transform these intention to treat estimates to obtain an estimate of the treatment on the treated by scaling by an estimate of the reciprocal of the proportion treated (Bloom 1984). As reported in Baker and Milligan (2008a) between 25 and 35 percent of women giving birth in Canada in this period are either not eligible for or do not claim maternity leave benefits. Therefore we can scale the estimates by $1.54(1 / 0.65)$ or $1.33(1 / 0.75)$ to obtain an estimate of the treatment on the treated. For example, using the 1.54 scale the increase in time at home for the treated implied by the regression discontinuity estimate of 2.271 leads to an estimate of treatment on the treated of about 3.5 months. This is a substantial increase over the average leave taken before the reform.

In Table 1 we continue the exploration of any changes in observable inputs to child development using our two-stage estimator. We provide estimates of equation (2) for inputs measured at different ages between 13 and 71 months. In the first row is an estimate of the change in the number of months the mother was at home in the child's first year of life, as a complement to figure 1. For each age group there is strong evidence that the reform of the leave laws led to an increase in the number of months mothers were at home in their child's first year of life. The estimates of the individual YOB effects (relative to the estimate for the 1998 cohort) underlying these regressions are reported in appendix table A1.

\footnotetext{
${ }^{21}$ We use a linear control for time, with different slopes allowed on either side of the discontinuity. We included all births in the 1998-2002 window, except those in a two-week period before and after December 31, 2000.
} 
Absent cohort attrition the estimates of the increase in time at home in the first year should be the same when measured at the different points of age. They are in fact very similar ranging from just over two to two and a quarter months; each of them also matches our regression discontinuity estimate for the $48-71$ month age group. ${ }^{22}$

In the next 3 rows we investigate the circumstances surrounding mothers' subsequent return to work. In row two the dependent variable is an indicator of whether the mother has returned to work by the indicated age range. In each case the estimate is very small and statistically insignificant. The estimates of the corresponding $Y O B$ do not indicate an effect of the reform. There is no evidence here that it led to any permanent withdrawal from the labor market.

The next row contains results for the continuity of employment since the initial return, conditional on going back to work. With the exception of the impact at 25-39 months- $0.061-$ the estimates are quite small and all are statistically significant. The individual YOB estimates reveal that the result for the middle age category reflects primarily a particularly low level of continuous employment for the 2000 birth cohort rather an effect correlated with the reform. ${ }^{23}$

In row 4 are the results for hours of work at the return (again conditional on having returned). Here we do see a statistically significant result when measured at ages 13-24 months. The $Y O B$ estimates reveal particularly high hours for the 2001 cohort. The estimate at $42-71$

\footnotetext{
${ }^{22}$ There are also very similar to estimates reported in Baker and Milligan (2008a) that included data for the 2003 birth cohort. We do not include the 2003 birth cohort in this analysis because the cognitive scores for these children, while collected, have not yet been publicly released.

${ }^{23}$ Note the regression for the 48-71 month olds for this variable and the next omits the observation for the 1998 birth cohort. This appears to be due to an incomplete carry forward of information from previous waves for this cohort in the original survey data. Very few observations for this birth cohort had non-missing values for this variable
} 
months is of similar magnitude but statistically insignificant. In this case it is a particularly large jump for the 2002 cohort driving the overall result.

The next two rows look at the mothers' current employment: whether she is currently employed and whether she worked 20 or more hours per week at a job held in the last 12 months. The estimates for current work are all negative, and at ages 41-72 months, there is a statistically significant drop of over 3 percentage points. In this latter case the $Y O B$ results indicate more of a downward trend across birth cohorts than a discrete jump at the time of the reform. The estimates for $20+$ hour workweeks are uniformly small, although again the result at $42-71$ months is statistically significant.

The next two rows investigate the family circumstances the child grew up in, through the presence of older and younger siblings. There is little evidence here or in the $Y O B$ effects that the reform had a significant effect on the spacing of births or total fertility up to this point.

In the final row are results for whether the child is in non-parental care. Unfortunately the gateway question for this section of the survey was changed in the most recent wave of the NLSCY, so the results for the 2001 and 2002 cohorts at ages 42-71 months are not comparable to those for the earlier cohorts. At earlier ages, however, there is no evidence of a change in the use of non-parental care with the reform.

One additional observable input to child development is family income. The income information in the NLSCY is not of high quality. The survey respondent (the person most knowledgeable about the child) supplies information for each member of the family. The reference period for the report is the previous 12 months, which is not a calendar year and varies across respondents depending on which month of the year they are interviewed. 
As a result, in Table 2 we use data from the LFS to examine family resources. The LFS collects information on individuals' weekly earnings, hourly earnings, and their economic family's weekly earnings. In addition to the resources questions, the LFS also provides information on labor market activity, which we use to corroborate the results in Table 1. The age groupings are slightly different than those in table 1 but span the same interval from 13 to 71 months. ${ }^{24}$ The corresponding year of birth estimates can be found in Appendix table A3.

In the first 4 rows are the results for labor force status. The estimates for employment, small and statistically insignificant, mostly agree with those from the NLSCY although they are generally of opposite sign. The one exception is the result at 13-35 months which while small is statistically significant. Separately the working mothers into "employed, at work" and "employed, absent" (not shown) reveals that this change in employment is the result of an increase in the latter category. This could reflect a small post-reform movement of mothers into employment to qualify for leave for subsequent births.

The results for full-time work and not in the labor force are also mostly small and statistically insignificant. Finally, there is a small positive and statistically insignificant increase in mothers' usual weekly hours for the post-reform cohorts. Overall, consistent with Table 1 there is no substantive evidence of a change in mothers' labor supply across the birth cohorts used in the analysis.

The next rows contain the results for real earnings. Neither the estimates for mothers' weekly earnings or their hourly wages indicate a significant advantage for either the pre- or post-

\footnotetext{
${ }^{24}$ The year of birth is not directly reported in the LFS. Instead, we identify the year of birth for children by selecting a sample of children in January of each year. We observe the age of the child and from that we can infer the year of birth - with the assumption that the child has not celebrated a birthday between January $1^{\text {st }}$ and the survey date. The questions in the LFS relate to the week containing the $15^{\text {th }}$ of the month, so we will misattribute the year of birth on average for $15 / 365=4$ percent of our sample.
} 
reform birth cohorts, with the exception of the results at ages 60-71 months. There is slightly more action in the results for the economic family's weekly earnings. The estimates are consistently positive, statistically significant at least at the 10 percent level, and as large as $\$ 80.00$ at age 5 (although not substantially large at younger ages).

We create real earnings by converting the earnings reports to 2002 dollars using the Consumer Price Index. In the presence of a general upward trend in wages across years, our estimates here will attribute to the policy what is really just a trend in real wage growth. For this reason, we have also re-estimated these regressions deflating earnings by the growth in the Industrial Aggregate Wage from Statistics Canada's Survey of Employment Payrolls and Hours (catalogue 72-002-XIB). These results, reported in Appendix table A2, provide less evidence of an increase in earnings across birth cohorts, although a $\$ 44$ per week family earnings advantage for the post-reform birth cohorts at age 5 remains.

There is no strong evidence here of substantial differences in family resources across the birth cohorts at ages up to 6 years. The most conservative conclusion is that there may be a small advantage for the post-reform cohorts at the ages the cognitive and behavioral tests were administered. However, this would presumably reinforce any positive impacts of the increase in maternal care and breastfeeding.

In the next 5 rows of Table 2 we examine measures of maternal care that are available in the LFS. ${ }^{25}$ First up are indicators that the mothers of these children work part-time, are not available for work or not looking for work because they are caring for their own children. In no case is there evidence of a change between the pre- and post-reform birth cohorts. Next are variables that capture whether the mother has been without work since the child was born. To

${ }^{25}$ The LFS does not provide any direct information on whether the child is in non-parental care. 
construct these variables we compare the year the mother last worked to the child's year of birth. For the "YBB" variable we code the mother as not working since giving birth if the date of last employment is the year before the year of birth. For the "YOB" measure we code the mother as not working since giving birth if the date of last employment is the same as the year of birth. Using the YBB method we miss some mothers who have in fact stayed at home since their child's birth. Using the YOB method we code some mothers as having stayed at home, who might have instead returned to work for a short period post birth. That said, the two methods lead to very similar conclusions. There is no evidence of a pre/post-reform change in the proportion of mothers staying home with their children, which is in agreement with the direct evidence on whether the mother returned to work post birth from the NLSCY.

Finally, in the last two rows we look for changes in family structure through the presence of younger or older siblings. Echoing the results from the NLSCY, there is no evidence here of a change.

The results from the LFS reinforce the conclusion from the NLSCY in Figure 1 and Table 1. There is little systematic evidence in either the NLSCY or LFS data of differences in observable inputs to child development between the pre- and post-reform birth cohorts at ages 1 through 5. This is consistent with our identifying assumption: the leave reform had concurrent effects on potentially important contributors to child development but did not affect these inputs across birth cohorts at ages greater than 12 months. That is, our results on cognitive and behavioral measures can be attributed with some confidence directly to the increase in maternal care in the first year of life and are not noticeably contaminated by changes in parental inputs after 12 months. 
We now turn to the cognitive results. Because of its prevalence in the literature, we start with the analysis of the PPVT, before moving on to other measures. Figures $2 \mathrm{a}$ and $2 \mathrm{~b}$ show the average PPVT scores by quarter of birth (weighted by the inverse of the variance). The PPVT score is standardized to have a mean of 100 and a standard deviation of 15 , with age norming by 2 month age groups. The first of these two PPVT graphs in Figure 2a indicates no discernable impact of the extra maternal time on PPVT as measured at ages 4 and 5. The y-axis in Figure 2a, however, shows the full range from zero, so this graph may miss any subtle changes around the mean of 100 . For that reason, in Figure $2 b$ we scale the $y$-axis to show only the range from 95 to 105. Again, there is no strong pattern on either side of the policy reform. A regression discontinuity analysis on these quarterly data (using the same specification described above for time at home in the first year) generates an estimate of -0.662 (1.716). Given the standard deviation of 15 points, not only is this a small point estimate, but it is also quite precisely estimated.

In Table 3 are the two-stage results for PPVT. The estimate using birth cohorts 1998 through 2002 indicates a decrease in the PPVT score of 2.2 points or almost 15 percent of a standard deviation. This result agrees in sign with the regression discontinuity estimate although it is clearly larger. Scaling up this intent to treat effect by our estimate of the proportion treated, the result would be 3.3 points or 22 percent of a standard deviation for the treated. The estimate is significant at the 10 percent level. The underlying $Y O B$ estimates are reported in Figure 3. While not inconsistent with this being an effect of the leave reform, the pattern here is not as stark as that for the time at home in the first year. For example, the conditional differences in PPVT between the 1998 and 1999 cohorts, or the 1999 and 2000 cohorts are as large as the estimate of POST. This is due to a large positive YOB effect for the 1999 cohort. 
To demonstrate the contribution of the 1999 birth cohort to the result in the second column we report an estimate of POST when the YOB effect for this birth cohort is excluded. The resulting estimate is still negative and statistically significant although not as large. While it is clear that the 1999 birth cohort contributes to the magnitude of the estimate in the first column, it alone is not driving the negative result.

Another perspective on whether the 1999 birth cohort is an outlier can be obtained by adding more pre-reform birth cohorts to the estimation. When we do this, however, we draw on pre-reform cohorts that are further temporally from our post reform cohorts and therefore, potentially not as comparable. To try to minimize any bias we make a small adjustment adding only the 1997 cohort to the sample. Interestingly, the estimate of the increase in mothers' time at home in the first year when we add the 1997 cohort is 2.161 months, which is almost identical to the estimate of 2.143 months using the 1998-2002 cohorts, as reported in Table 1.

The results for PPVT when we add the 1997 birth cohort to the sample are reported in the third column. The estimate of POST remains negative, is now larger than the result in the first column, and is statistically significant at the 5 percent level. The YOB effects for this result are reported in figure 3. It is now clear why the $Y O B$ estimate for the 1999 cohort is large relative to the estimate for the 1998 cohort. However, from this perspective the estimate for the 1999 cohort is no more an outlier than the estimate for the 1998 cohort. The results for the post reform cohorts stand out for both being consistently negative and marginally outside the "regular" variation in the $Y O B$ effects.

One way to bring further evidence to bear on the question of causality is to compare results across samples that differ in the proportion of treated individuals or in the impact of the leave reform on developmental inputs. In the latter case, assuming homogeneous response to the 
inputs, we might expect those who received larger increases in inputs would display larger impacts. Our first pass at this approach is to examine children whose mothers returned to work within one year of giving birth. Intuitively this sample should contain a higher proportion of mothers who were eligible and claimed EI maternity leave benefits. Of course the proportion of mothers returning within a year might be affected by the leave reform, although Baker and Milligan (2008a) report that this effect is empirically small.

Consistent with our working assumption, the increase in maternal care in the first year in this smaller sample at almost 3 months is larger than the estimates for the full sample (Table 1), but comparable to the result when the estimates are scaled for treatment. The estimated impacts on PPVT for this sample are also larger and still negative. The pattern in the YOB estimates mirrors that seen for the full sample; we can rule out any positive effect, and there is supportive but not conclusive evidence of a small negative effect.

In the next two rows we report results by the gender of the child. An interesting fact not reported in previous research is that the mothers of female children tend to stay home longer in the first year, ${ }^{26}$ and their time at home responds more to the leave reforms. In the male sample the increase in time at home in response to the reform is a statistically significant 2 months, while the response in the female sample is a statistically significant $2 \frac{1}{4}$ months. Of course in this comparison the assumption of homogeneous responses in the two samples may be tenuous.

While the estimates for PPVT are negative for both males and females, the result for males is larger and more consistently statistically significant. The underlying $Y O B$ estimates provide some perspective on the previous results. First the 1999 birth cohort continues to be an outlier in both samples. However, when we add the 1997 birth cohort to the sample the results

\footnotetext{
${ }^{26}$ Pre-reform baseline periods at home in the first year by gender to be reported in future draft. $\mathrm{RDC}$ vetting rules discourage the release of mean statistics at the early stages of a project.
} 
are comparable to what we report in the first column. Second, in both the male and female samples there is no obvious jump in the estimates between the 2000 and 2001 birth cohorts. Instead, the estimates for POST appear to be the result of regular inter-cohort variation.

In the next two rows of Table 3 we further refine the sample selecting only males and females whose mothers returned to work in the first year post-birth. In these samples there is again a gender difference in the increase in time mothers stayed at home in the first year: the increase is more than a third of month larger for mothers of females. The estimated impact on PPVT for males larger is larger than in the full sample (of males) consistent with our assumption of a higher level of treatment once we restrict to the sample to mothers who returned to work in the first year. The estimate for females, however, is smaller than in the full sample (of females).

In the final two rows we present estimates by the mother's level of education. "Low education" is defined by achievement up to a high school diploma, and "high education" is defined by all higher levels. There is again a clear difference between these two groups in the response of time at home in the first year to the reform. In the high education group it increases by an additional half month. The estimated impact of PPVT is correspondingly larger in the high education sample, although not statistically significant. In neither sample do the YOB estimates provide strong evidence of an impact of the law change.

The clear message of these results is the change in maternity leave law had no discernable positive impact on PPVT scores. Whether there is a negative impact is not as unambiguous. One way of interpreting the patterns in Figure $3 \mathrm{a}$ and especially figure $3 \mathrm{~b}$ is as regular inter-cohort variation in the scores. The estimates for the samples of children whose mothers returned to work in their first year are typically larger than the full sample results, but not by a full a one third to one half we obtain when we scale the estimates from the full sample. 
In making this argument we emphasize that the leave reform had large impacts on inputs thought important to child development. We are examining an intervention that led to between 2 and 3 months of extra maternal care, and an additional month of breastfeeding. It is likely that the magnitude of our estimates of the leave reform on inputs would please policy makers. The predicted sign on development of these changes in inputs based on previous research is unambiguously positive. We also note the standard errors on our estimates are fairly modest. Even at the heightened critical values we must use, in the full sample we have the power to detect an effect of 2.7 points in the full sample or 18 percent of a standard deviation at the five percent level -10 percent of a standard deviation when we include the 1997 cohort. Most persuasively, the individual birth cohort estimates do not display the strong coherence with the reform that can be observed for the time at home input reported in Table 1, and Baker and Milligan (2008a and 2010).

Moving to other cognitive measures, in Table 4 we report the results for the Who Am I? test. Corresponding year of birth estimates appear in Appendix table A4. The estimates of POST in all of the samples are negative consistent with the results for the PPVT scores and typically small-less than one point. However, unlike the results for PPVT the YOB effects for the post reform cohorts are both positive and negative indicating no systematic impact of the reform. Another difference is that the estimates of POST are not larger in the samples of children whose mothers returned to work in their first year of life. Finally, none of the estimates are statistically significant at conventional levels.

The final column contains the results for the Know Your Numbers score. Again the estimates are uniformly negative, small and mostly statistically insignificant. In this case the point estimates are modestly larger in the samples restricted to mothers who returned to work 
within one year of birth. However, in no cases do the $Y O B$ estimates show a strong coherence with the reform.

In the final set of results we look for an impact of extra maternal time in the first year on behavior. We focus first on the hyperactivity inattention score. Figure 4 graphs the quarterly data, weighted by the inverse of the cell variance. There is no clear break before and after December 31, 2000 in the data. The regression discontinuity estimate, using the same specification as for months at home discussed above, is $-0.390(0.247)$.

In Table 5 are the regression results from the two-stage estimator. The estimate for the full sample indicates an increase in hyperactivity with the increase in leave. The YOB estimates in Appendix Table A5 show some coherence with the reform although the jump between the 1998 and 1999 birth cohorts is of similar magnitude as the jump between the 2000 and 2001 birth cohorts. To provide some perspective on whether either of these jumps is notable we can again add the 1997 birth cohort. The estimate of POST is reported in the second column while the underlying $Y O B$ effects are reported in Figure 5. These results suggest that there is indeed an outlying observation in the 1998 birth cohort, and furthermore nothing notable in the estimates for the post-reform cohorts. Omitting the 1998 YOB effect from the estimation leads to an estimate of POST of $0.123(0.045)$, consistent with this conclusion.

The point estimate for hyperactivity-inattention in the sample of mothers who returned within the first year is larger but so is the standard error. The results by gender are in the next two rows. Each is positive and statistically significant. For each sample there is a discrete jump in the estimates between the 2000 and 2001 birth cohorts, but also between the 1998 and 1999 cohorts. Further refining the inference by selecting males and females whose mothers returned to work in the first year leads to still bigger point estimates. In each case the YOB estimates are 
less supportive of a causal interpretation, showing a substantial increase in the index with the 2000 birth cohort. Finally, the results by mothers' education do not change this conclusion as in both samples the birth cohort estimates show unremarkable inter-cohort variation.

The other columns in Table 5 show the results for our other behavior measures: anxiety, physical aggression, and indirect aggression. These results reveal little change in behavior as a result of the change of the developmental inputs. Overall, the behavior results are consistent with the results of Baker and Milligan (2010) for these same children at ages up to 24 months. They are also consistent with the behavioral results for breastfeeding in Kramer et al. (2008a) for the PROBIT study. This is notable as many of the questions for this aspect of the PROBIT analysis are drawn from the NLSCY.

\section{Discussion}

The results presented in Tables 3 through 5 provide little evidence that the Canadian maternity leave reforms had a measurable positive impact on the cognitive and behavioral outcomes of children. This is despite the fact that the reforms did have a substantial impact on some potentially important developmental inputs - maternal care, full time maternal employment, non-licensed non-parental care, breastfeeding and exclusive breastfeeding duration — in ways that we would expect a positive impact on measures of development.

This conclusion is consistent with most evidence of the impact of maternity leave on developmental outcomes at older ages (Dustmann and Schonberg 2008, Liu and Skans 2009, Rasmussen 2009). Each of these studies has a credible identification strategy based on sharp changes in maternity leave laws. What makes the results here of particular interest is the measurement of children's outcomes at ages 4 and 5 . The evidence base for maternity leave 
policies is typically the developmental outcomes of children at ages just prior to school entry. It is precisely at these ages that we find no positive effect.

These findings do not so much raise questions for research on the consequences of maternal employment, non-parental care or breastfeeding for child development, than for the use of this research as a basis for maternity leave policy. As noted above much of this research suggests that the developmental inputs that maternity leaves can influence are important to child development and this evidence has clearly been compelling for policymakers. The results here suggest that, at the least, the maternity leave reform analyzed here did not affect these inputs sufficiently and/or affected a different part of the population, such that the hypothesized outcomes were not realized.

There are a number of qualifications to these conclusions. First, we do not analyze the impact of maternity leave over the first 6 months of life. We cannot rule out the possibility that substantial benefits flow from leaves in this range. We do note, however, that in developed countries even in the absence of formal leave provisions mothers do not typically return to work in the first months following birth. Baker and Milligan (2008b), for example, find that shorter leaves have little impact on time at home, but simply relabel time out of the labor force as time employed and on leave. So the relevant question is whether a leave mandate in the 4-6 month range brings substantial benefits, since leaves of shorter duration are less likely to substantially change the maternal time input.

Second, our evidence is for specific and measurable dimensions of child development. There are other dimensions, some poorly measured or immeasurable, that may directly improve from the change in developmental inputs induced by maternity leave reform. However, our results do speak to the evidence base typically cited in maternity leave legislation. 
Third, it is important to remember that maternity leaves clearly have potential benefits for other groups in the population. They provide mothers a period to recover physically from giving birth and to enjoy time with her newborn. They also contribute to family/work balance. Licensed care for very young children can be more difficult to find and relatively costly.

\section{Comparison with Previous Results from the Breastfeeding Literature}

Much of our discussion has focused on the potential impact of the increase in maternal time input on measures of development. However, the reform also had a large impact on breastfeeding (Baker and Milligan 2008a). Recent research on the link between breastfeeding and cognitive development in Kramer et al. (2008b) provides an interesting perspective on the results presented here. They report an increase in a measure of IQ of just over one-third of a standard deviation for the increase in breastfeeding induced by their experiment. ${ }^{27}$ This is quite large and certainly within our power to detect.

Both the baseline levels of breastfeeding and the absolute increases in breastfeeding in our study are fairly similar to that in Kramer et al's (2008b) study. The largest differences in the baselines are in the incidence of breastfeeding, which is $100 \%$ in the PROBIT study and $86.3 \%$ in Canada before the reform, and in the probability of breastfeeding 6 months or more, which is $36 \%$ in the PROBIT study and $46 \%$ in Canada prior to the reform. In contrast the differences across the two studies in the baseline probabilities of breastfeeding at least 3, 9 and 12 months are just 3, 0.9 and 1.7 percentage points respectively.

${ }^{27}$ The measure of cognitive development is the Wechsler Abbreviated Scales of Intelligence. 
In Figure 6 we report the absolute percentage increase in breastfeeding at different durations induced by the PROBIT experiment and the Canadian maternity leave reform. ${ }^{28}$ While both studies are intent to treat designs, the proportion not treated in the Canadian case is likely higher. ${ }^{29}$ We therefore also report the estimated absolute percentage increase for the Canadian case using the 1.54 scaling factor. Once the adjustment for treatment is made there is a significant coherence in the increase in breastfeeding in the two studies. This means that, for about the same increase in breastfeeding, there are substantial differences in measured cognitive impacts. We find no positive impact, while Kramer et al. (2008b) find a large impact.

There are some potentially important differences between the two studies, including the facts that the PROBIT study induced a much larger increase in exclusive breastfeeding, ${ }^{30}$ and the Canadian reform induced a contemporaneous increase in maternal care that was not a feature of the PROBIT treatment. ${ }^{31}$ However, commentators have wondered how the results of the PROBIT study translate to more developed countries (Lawrence 2001), and the results here corroborate the findings for behavior but not those for cognitive development.

\footnotetext{
${ }^{28}$ We construct the figure based on table 3 of Kramer et al. (2001), and differences in the simple averages of the pre and post reform probabilities reported in figure 3 of Baker and Milligan (2008a).

${ }^{29}$ The proportion not treated in the PROBIT study is not reported. Presumably all medical professionals at the experimental test sites received the training so the loss in treatment would be through them not communicating their new knowledge to the mothers under their care.

${ }^{30}$ The proportion of mothers exclusively breastfeeding at 3 months increased from 6.4 percent to 43.3 percent and at 6 months from 0.6 percent to 7.9 percent. The corresponding increase at 3 months in Canada was from 53.8 to 59.3 percent, and at 6 months from 19.5 percent to 25.1 percent.

${ }^{31}$ In Belarus the duration of maternal care is typically to age 3 (Lawrence 2001).
} 


\section{Conclusions}

We investigate the impact of a change in Canada's maternity leave laws of children's cognitive and behavioral development at ages 4 and 5. The change in the law increased the duration of job-protected, partially-compensated leave from approximately 6 months to one year. This led to large contemporaneous changes in important inputs to children's development: maternal care, maternal full time employment, unlicensed non-parental care, and breastfeeding duration. However, we find that these changes had no positive impact on indices of cognitive and behavioral development. 


\section{References}

Achenbach, T. M., and C. Edelbrock (1983), Manual for the Child Behavior Checklist and Revised Child Behavior Profile. Burlington, VT: Queen City Printers.

Baker, Michael and Kevin Milligan (2008a), "Maternal Employment, Breastfeeding, and Health: Evidence from Maternity Leave Mandates," Journal of Health Economics, Vol. 27, July, 871887.

Baker, Michael and Kevin Milligan (2008b), "How does job-protected maternity leave affect mothers' employment?" Journal of Labor Economics, Vol. 26, No. 4, pp. 655-691.

Baker, Michael and Kevin Milligan (2010), "Evidence from maternity leave expansions of the impact of maternal care on early child development," Journal of Human Resources, 45, Winter, $1-32$.

Baker, Michael, Jonathan Gruber, and Kevin Milligan (2008), "Universal Childcare, Maternal Labor Supply, and Family Well-being," Journal of Political Economy, Vol. 116, No. 4, pp. 709745 .

Behar, Lenore, and Samuel Stringfield (1974), “A Behavior Rating Scale for the Preschool Child," Developmental Psychology 10 (September), pp. 601-10.

Belsky, J. (2006), "Early child care and early child development: Major findings of the NICHD study of early child care," European Journal of Developmental Psychology, Vol. 3, No. 1, pp. $95-110$.

Bernal, R. (2008), "The Effect of Maternal Employment and Child Care on Children's Cognitive Development.” International Economic Review, Vol. 49, No. 4, pp. 1173-1209.

Bernal R and M Keane, (2009) "Web Appendices to Accompany 'Child Care Choices and Children's Cognitive Achievement: The Case of Single Mothers"', http://economia.uniandes.edu.co/profesores/planta/Bernal_Raquel/documentos_de trabajo

Bloom. Howard S. (1984), "Accounting for no-shows in experimental evaluation designs," Evaluation Review, Vol. 8, pp. 225-246.

Brooks-Gunn, Jeanne, Wen-Jui Han, and Jane Waldfogel (2002), "Maternal Employment and Child Cognitive Outcomes in the First Three Years of Life: The NICHD Study of Early Child Care," Child Development, Vol, 73, No. 4, pp. 1052-1072.

Brusentsev, Vera and Wayne Vroman (2007), "Compensating for Birth and Adoption", The Urban Institute. 
Boyle, Michael H., David R. Offord, Yvonne Racine, Jan E. Fleming, Peter Szatmari, and Mark Stanford (1993), "Evaluation of the Revised Ontario Child Health Study Scales," Journal of Child Psychology and Psychiatry Vol. 34 (February), pp. 189-213.

Carneiro, Pedro, Loken, Katrine and Kjell G. Salvanes, (2008) “A Flying Start? Maternity Leane and Long Term Outcomes for Mother and Child", manuscript.

Case, Robbie, Okamoto, Yukari, Griffin, Sharon, McKeough, Anne, Bleiker, Charles Henderson, Barbara, Stephenson, Kimberly Marra, Siegler, Robert S., and Daniel P. Keating, (1996). The role of central conceptual structures in the development of children's thought. Monographs of the Society for Research in Child Development, 61,1/2.

Commonwealth of Australia (2009), Australia's Paid Parental Leave Scheme, CanPrint Communications Pty Ltd.

de Lemos, M. and Doig, B. (1999), Who Am I?: Developmental Assessment: Melbourne. ACER.

Der, Geoff, G. David Batty, and Ian J. Deary (2006), "Effect of breast feeding on intelligence in children: prospective study, sibling pairs analysis, and meta-analysis," British Medical Journal, October $4^{\text {th }}$.

Dustmann, Christian, and Uta Schonberg (2008), "The Effect of Expansions in Leave Coverage on Children's Long-Term Outcomes," Bonn: Institute for the Study of Labor Working Paper No. 3605 .

Donald, Stephen G. and Kevin Lang (2007), "Inference with Difference in Differences and Other Panel Data," The Review of Economics and Statistics, Vol. 89, No. 2, pp. 221-233.

Employment Relations Directorate (2006), The Maternity and Parental Leave (Amendment) Regulations 2006 and the Paternity and Adoption Leave (Amendment) Regulations 2006, Full Regulatory Impact Assessment, London: Department of Trade and Industry, June.

Hanratty, Maria and Eileen Trzcinski (2009), "Who Benefits from Expanded Paid Parental Leave? Impact of Parental Benefit Expansions in Canada on Mothers' Employment after Birth," Journal of Population Economics, Vol. 22, No. 3, pp. 1432-1475.

He, Daihai and David J.D. Earn (2007), "Epidemiological effects of seasonal oscillations in birth rates,” Theoretical Population Biology, Vol. 72, No. 2, pp. 274-291.

Hill, J., Jane Waldfogel, Jeanne Brooks-Gunn, and W.-J. Han (2005), "Maternal Employment and Child Development: A Fresh Look Using Newer Methods," Developmental Psychology, Vol. 41, No. 6, pp. 833-850.

James-Burdumy, Susanne (2005), “The Effect of Maternal Labor Force Participation on Child Development," Journal of Labor Economics, Vol. 23, No. 1, pp. 177-211. 
Kramer, Michael S. Beverley Chalmers, Ellen D. Hodnett, Zinaida Sevkovskaya, Irina Dzikovich, Stanley Shapiro, Jean-Paul Collet, Irina Vanilovich, Irina Mezen, Thierry Ducruet, George Shishko, Vyacheslav Zubovich, Dimitri Mknuik, Elena Gluchanina, Viktor Dombrovskiy, Anatoly Ustinovitch, Tamara Kot, Natalia Bogdanovich, Lydia Ovchinikova, Elisabet Helsing for the PROBIT Study Group (2001), "Promotion of Breastfeeding Intervention Trial (PROBIT): A Randomized Trial in the Republic of Belarus" Journal of American Medical Association, January 24/31—Vol 285, No. 4, pp. 413-420.

Kramer MS, Matush L, Vanilovich I, Platt RW, Bogdanovich N, Sevkovskaya Z, Dzikovich I, Shishko G, Mazer B for the Promotion of Breastfeeding Intervention Trial (PROBIT) Study Group (2007a), "Does prolonged and exclusive breastfeeding reduce the risk of allergy and asthma? New evidence from a large randomized trial," British Medical Journal, Vol. 335, pp. $815-820$

Kramer MS, Fombonne E, Igumnov S, Vanilovich I, Matush L, Mironova E, Bogdanovich N, Tremblay RE, Chalmers B, Zhang X, Platt RW for the Promotion of Breastfeeding Intervention Trial (PROBIT) Study Group (2008a). "Effects of prolonged and exclusive breastfeeding on child behavior and maternal adjustment: Evidence from a large randomized trial," Pediatrics, Vol. 121, pp. e435-e440.

Kramer MS, Aboud F, Mironova E, Vanilovich I, Platt RW, Matush L, Igumnov S, Fombonne E, Bogdanovich N, Ducruet T, Collet J-P, Chalmers B, Hodnett E, Davidovsky S, Skugarevsky O, Trofimovich O, Kozlova L, Shapiro S for the Promotion of Breastfeeding Intervention Trial (PROBIT) Study Group (2008b). "Breastfeeding and Child Cognitive Development: New evidence from a large randomized trial," Arch Gen Psychiatry, Vol. 65, pp. 578-584.

Lawrence, Ruth A. (2001), "Breastfeeding in Belarus," Journal of American Medical Association, Vol. 285, pp. 463-464.

Lefebvre, Pierre Merrigan, Philip and Matthieu Verstraete, (2008) Childcare Policy and Cognitive Outcomes of Children: Results from a Large Scale Quasi-Experiment on Universal Childcare in Canada, CIRPEE, Cahier de recherche/Working Paper 08-23.

Loeb, Susanna, Margaret Bridges, Daphna Bassok, Bruce Fuller, and Russell W. Rumberger (2007), "How much is too much? The influence of preschool centers on children's social and cognitive development," Economics of Education Review, Vol. 26, No. 1, pp. 52-66.

Magnuson, Katherine A., Christopher Ruhm, and Jane Waldfogel (2007), "Does prekindergarten improve school preparation and performance?" Economics of Education Review, Vol. 26, No. 1, pp. 33-51.

Marshall, Katherine, "Father's use of Paid Parental Leave, Perspectives on Labour and Income, June 2008, 5-14.

O’Brien Caughy, Margaret, Janet DiPietro, and Donna Strobino (1994), "Daycare Participation as a Protective Factor in the Cognitive Development of Low-income Children," Child 
Development, 65, 457-471.

Liu, Qian and Oskar Nordstrom Skans, (2009) "The Duration of Paid Parental Leave and Children's Scholastic Performance”. IZA Discussion Paper No. 4244.

Rasmussen, A.W., (2009) "Increasing the length of parents' birth-related leave: The effect on children's long-term educational outcomes", Labour Economics.

doi:10.1016/j.labeco.2009.07.007

Ray, Rebecca (2008), A Detailed Look at Parental Leave Policies in 21 OECD Countries, Washington DC: Center for Economic and Policy Research, September.

Ruhm, Christopher J. (2004) "Parental Employment and Child Cognitive Development," Journal of Human Resources, Vol. 39, No 1, pp. 155-192.

Rutter, Michael (1967), "Children's Behavior Questionnaire for Completion by Teachers: Preliminary Findings," Journal of Child Psychology and Psychiatry Vol. 8, pp. 1-11.

Schwartz, Kendra, Hannah J.S. D’Arcy, Brenda Gillespie, Janet Bobo, Marylou Longeway, Betsy Foxman (2002), "Factors associated with weaning in the first 3 months postpartum" Journal of Family Practice, Vol. 51, No. 5.

Tremblay, R. E., F. Vitaro, C. Gagnon, C. Piche, and N. Royer (1992), "The Prosocial Scale for the Preschool Behaviour Questionnaire: Concurrent and Predictive Correlates,"

International Journal of Behavioural Development Vol. 15, pp. 227-45.

Waldfogel, Jane (2006), What Children Need, Cambridge MA: Harvard University Press.

Weir, Kirk, and Gerard Duveen (1981), "Further Development and Validation of the Prosocial Behaviour Questionnaire for Use by Teachers," Journal of Child Psychology and Psychiatry Vol. 22, pp. 357-374.

Weir, Kirk, J. Stevenson, and P. Graham (1980), "Behavioral Deviance and Teacher Ratings of Prosocial Behavior," Journal of the American Academy of Child Psychiatry Vol. 19, No. 1, p. 68-77. 
Table 1: Estimated impact of longer maternity leave mandates on observable inputs to childhood development from the NLSCY

\begin{tabular}{lccc}
\hline & Age $48-71$ Months & Age 25-39 Months & Age 13-24 Months \\
\hline Time mother home in & $2.143^{* *}$ & $2.229^{* *}$ & $2.034^{* *}$ \\
first year & $(0.185)$ & $(0.317)$ & $(0.184)$ \\
Mother returned to work & -0.004 & -0.000 & -0.021 \\
post-Birth & $(0.015)$ & $(0.045)$ & $(0.032)$ \\
Continuous work post- & $\wedge 0.015$ & 0.061 & 0.017 \\
birth & $(0.009)$ & $(0.038)$ & $(0.011)$ \\
Hours at return to work & $\wedge 1.856$ & 0.297 & $1.719 *$ \\
& $(1.388)$ & $(0.768)$ & $(0.533)$ \\
Mother Currently & $-0.032^{* *}$ & -0.019 & -0.027 \\
Employed & $(0.007)$ & $(0.043)$ & $(0.012)$ \\
Mother worked 20+ & $0.017 * *$ & -0.006 & -0.011 \\
hours/week & $(0.004)$ & $(0.032)$ & $(0.021)$ \\
Child has younger & 0.007 & 0.018 & -0.013 \\
sibling(s) & $(0.019)$ & $(0.007)$ & $(0.006)$ \\
Child has older sibling(s) & -0.001 & -0.036 & -0.000 \\
& $(0.040)$ & $(0.026$ & $(0.065)$ \\
Child in care & N.A. & -0.029 & 0.000 \\
& & $(0.032)$ & $(0.010)$ \\
\hline
\end{tabular}

Notes: Number of observations equals 5 , except 4 where indicated by ${ }^{\wedge}$ as observation for the 1998 cohort is not available. $*$ and $* *$ indicate statistical significance at the $10 \%$ and $5 \%$ levels respectively. We report the coefficients (standard errors) for the POST variable described in the text. N.A. not available. 
Table 2: Estimated impact of longer maternity leave mandates on observable inputs to childhood development from the LFS

\begin{tabular}{|c|c|c|c|c|}
\hline & $\begin{array}{l}\text { Age } 60-71 \\
\text { Months }\end{array}$ & $\begin{array}{l}\text { Age } 48-59 \\
\text { Months }\end{array}$ & $\begin{array}{l}\text { Age } 36-47 \\
\text { Months }\end{array}$ & $\begin{array}{l}\text { Age 13-35 } \\
\text { Months }\end{array}$ \\
\hline Mother Employed & $\begin{array}{c}0.021 \\
(0.016)\end{array}$ & $\begin{array}{c}0.011 \\
(0.023)\end{array}$ & $\begin{array}{c}0.036 \\
(0.028)\end{array}$ & $\begin{array}{l}0.024 * * \\
(0.004)\end{array}$ \\
\hline Mother Employed Full Time & $\begin{array}{c}0.028 \\
(0.015)\end{array}$ & $\begin{array}{c}0.022 \\
(0.021)\end{array}$ & $\begin{array}{c}0.056 \\
(0.031)\end{array}$ & $\begin{array}{l}0.029 * \\
(0.009)\end{array}$ \\
\hline $\begin{array}{l}\text { Mother's Usual Weekly } \\
\text { Hours }\end{array}$ & $\begin{array}{c}1.137 \\
(0.527)\end{array}$ & $\begin{array}{c}0.486 \\
(0.472)\end{array}$ & $\begin{array}{c}1.109 \\
(0.479)\end{array}$ & $\begin{array}{c}0.287 \\
(0.401)\end{array}$ \\
\hline $\begin{array}{l}\text { Mother Not in the Labor } \\
\text { Force }\end{array}$ & $\begin{array}{l}-0.012 \\
(0.019)\end{array}$ & $\begin{array}{l}-0.001 \\
(0.019)\end{array}$ & $\begin{array}{l}-0.025 \\
(0.031)\end{array}$ & $\begin{array}{c}-0.027 * * \\
(0.006)\end{array}$ \\
\hline $\begin{array}{l}\text { Mother's Real Weekly } \\
\text { Earnings }\end{array}$ & $\begin{array}{l}40.100 * * \\
(5.834)\end{array}$ & $\begin{array}{c}12.857 \\
(25.189)\end{array}$ & $\begin{array}{c}0.098 \\
(27.034)\end{array}$ & $\begin{array}{l}-15.257 \\
(12.261)\end{array}$ \\
\hline $\begin{array}{l}\text { Mother's Real Hourly } \\
\text { Earnings }\end{array}$ & $\begin{array}{l}0.973 * * \\
(0.123)\end{array}$ & $\begin{array}{c}0.134 \\
(0.534)\end{array}$ & $\begin{array}{l}-0.684 \\
(0.517)\end{array}$ & $\begin{array}{l}-0.470 \\
(0.325)\end{array}$ \\
\hline $\begin{array}{l}\text { Economic Family's Real } \\
\text { Weekly Earnings }\end{array}$ & $\begin{array}{l}83.601 * * \\
(16.733)\end{array}$ & $\begin{array}{l}39.449 * * \\
(10.051)\end{array}$ & $\begin{array}{l}26.416^{*} \\
(10.507)\end{array}$ & $\begin{array}{c}2.244 \\
(16.578)\end{array}$ \\
\hline $\begin{array}{l}\text { Mother working PT to care } \\
\text { for own children }\end{array}$ & $\begin{array}{c}0.002 \\
(0.004)\end{array}$ & $\begin{array}{c}0.002 \\
(0.010)\end{array}$ & $\begin{array}{c}-0.035 * * \\
(0.011)\end{array}$ & $\begin{array}{c}0.007 \\
(0.010)\end{array}$ \\
\hline $\begin{array}{l}\text { Mother not available for } \\
\text { work-caring for own children }\end{array}$ & $\begin{array}{l}-0.001 \\
(0.001)\end{array}$ & $\begin{array}{l}-0.002 \\
(0.003)\end{array}$ & $\begin{array}{l}-0.003 \\
(0.002)\end{array}$ & $\begin{array}{c}0.000 \\
(0.004)\end{array}$ \\
\hline $\begin{array}{l}\text { Mother not looking for work- } \\
\text { caring for own children }\end{array}$ & $\begin{array}{c}0.000 \\
(0.002)\end{array}$ & $\begin{array}{l}-0.005 \\
(0.004)\end{array}$ & $\begin{array}{l}-0.002 \\
(0.005)\end{array}$ & $\begin{array}{c}0.002 \\
(0.006)\end{array}$ \\
\hline Stay at Home Mother (YBB) & $\begin{array}{l}-0.016 \\
(0.005)\end{array}$ & $\begin{array}{c}0.002 \\
(0.006)\end{array}$ & $\begin{array}{l}-0.010 \\
(0.018)\end{array}$ & $\begin{array}{c}0.013 \\
(0.007)\end{array}$ \\
\hline $\begin{array}{l}\text { Stay at Home Mother: } \\
\text { (YOB) }\end{array}$ & $\begin{array}{l}-0.013 * \\
(0.005)\end{array}$ & $\begin{array}{l}-0.003 \\
(0.015)\end{array}$ & $\begin{array}{l}-0.006 \\
(0.022)\end{array}$ & $\begin{array}{c}0.007 \\
(0.007)\end{array}$ \\
\hline Mother has younger children & $\begin{array}{l}-0.018 \\
(0.009)\end{array}$ & $\begin{array}{l}-0.007 \\
(0.013)\end{array}$ & $\begin{array}{c}0.031 * * \\
(0.008)\end{array}$ & $\begin{array}{c}0.007 \\
(0.009)\end{array}$ \\
\hline Mother has older children & $\begin{array}{l}-0.057 \\
(0.026)\end{array}$ & $\begin{array}{l}-0.039 \\
(0.023)\end{array}$ & $\begin{array}{c}-0.003 \\
(0.008)\end{array}$ & $\begin{array}{c}0.002 \\
(0.018)\end{array}$ \\
\hline
\end{tabular}

Notes: Number of observations equals $5 .{ }^{*}$ and $* *$ indicate statistical significance at the $10 \%$ and $5 \%$ levels respectively. We report the coefficients (standard errors) for the POST variable described in the text. 
Table 3: Estimated impact of longer maternity leave mandates on PPVT

\begin{tabular}{lccc}
\hline Sample & $\begin{array}{c}1998-2002 \text { Birth } \\
\text { Cohorts }\end{array}$ & $\begin{array}{c}\text { Omit } \text { YOB effect for } \\
\text { 1999 Birth Cohort }\end{array}$ & $\begin{array}{c}\text { 1997-2002 Birth } \\
\text { Cohorts }\end{array}$ \\
\hline Full Sample & $-2.155^{*}$ & $-1.336^{*}$ & $-2.203^{* *}$ \\
& $(0.864)$ & $(0.403)$ & $(0.581)$ \\
Mother returned to work & $-2.677^{*}$ & $-1.840^{*}$ & $-2.618^{* *}$ \\
in first year & $(0.929)$ & $(0.541)$ & $(0.630)$ \\
Males & $-2.669^{*}$ & -1.847 & $-2.907^{* *}$ \\
& $(1.078)$ & $(0.986)$ & $(0.803)$ \\
Females & -1.566 & -0.782 & $-1.394^{*}$ \\
& $(0.900)$ & $(0.509)$ & $(0.647)$ \\
Males, mother returned & $-3.917^{*}$ & -2.492 & $-4.026^{* *}$ \\
in first year & $(1.591)$ & $(0.920)$ & $(1.113)$ \\
Females, mother returned & $-1.198^{* *}$ & $-1.028^{* *}$ & $-0.999^{* *}$ \\
in first year & $(0.251)$ & $(0.199)$ & $(0.221)$ \\
Mother Low Education & -1.876 & $-2.175^{*}$ & $-2.176^{* *}$ \\
& $(0.994)$ & $(0.899)$ & $(0.612)$ \\
Mother High Education & -2.135 & -1.231 & $-2.084^{*}$ \\
& $(0.913)$ & $(1.368)$ & $(0.765)$ \\
\hline
\end{tabular}

Notes: Number of observations equals $5 . *$ and $* *$ indicate statistical significance at the $10 \%$ and 5\% levels respectively. We report the coefficients (standard errors) for the POST variable described in the text. All results for children aged 48-71 months. 
Table 4: Estimated impact of longer maternity leave mandates other measures of children's cognitive development

\begin{tabular}{lcc}
\hline Sample & Who Am I? & Know Your Numbers \\
\hline Full Sample & -0.989 & -0.058 \\
& $(1.179)$ & $(0.047)$ \\
Mother returned to work & -0.863 & -0.077 \\
in first year & $(1.169)$ & $(0.068)$ \\
Males & -0.920 & -0.045 \\
& $(1.643)$ & $(0.096)$ \\
Females & -1.096 & -0.069 \\
& $(0.847)$ & $(0.047)$ \\
Males, mother returned & -0.798 & -0.081 \\
in first year & $(1.542)$ & $(0.144)$ \\
Females, mother returned & -0.882 & $-0.072 * *$ \\
in first year & $(0.948)$ & $(0.021)$ \\
Mother Low Education & -0.935 & -0.005 \\
& $(1.769)$ & $(0.060)$ \\
Mother High Education & -1.027 & -0.071 \\
& $(1.037)$ & $(0.042)$ \\
\hline
\end{tabular}

Notes: Number of observations equals $5 . *$ and $* *$ indicate statistical significance at the $10 \%$ and $5 \%$ levels respectively. We report the coefficients (standard errors) for the POST variable described in the text. All results for children aged 48-71 months. 
Table 5: Estimated impact of longer maternity leave mandates on children's behavior

\begin{tabular}{lccccc}
\hline \multicolumn{2}{c}{ Hyperactivity } & Anxiety & $\begin{array}{c}\text { Physical } \\
\text { Aggression }\end{array}$ & $\begin{array}{c}\text { Indirect } \\
\text { Aggression }\end{array}$ \\
\hline & $\begin{array}{c}1998-2002 \\
\text { birth cohorts }\end{array}$ & $\begin{array}{c}1997-2002 \\
\text { birth cohorts }\end{array}$ & & & \\
\hline Full Sample & $\begin{array}{c}0.252^{* *} \\
(0.079)\end{array}$ & $\begin{array}{l}0.183^{*} \\
(0.076)\end{array}$ & 0.061 & -0.055 & 0.011 \\
Mother returned to & 0.310 & 0.301 & 0.033 & -0.068 & -0.010 \\
work in first year & $(0.217)$ & $(0.146)$ & $(0.082)$ & $(0.201)$ & $(0.107)$ \\
Males & $0.318^{* *}$ & $0.234 *$ & -0.073 & -0.093 & -0.037 \\
Females & $(0.093)$ & $(0.079)$ & $(0.047)$ & $(0.141)$ & $(0.219)$ \\
Males, mother & $0.201^{*}$ & 0.145 & 0.207 & -0.023 & 0.059 \\
returned in first year & $(0.065)$ & $(0.077)$ & $(0.174)$ & $(0.225)$ & $(0.121)$ \\
Females, mother & 0.407 & 0.341 & -0.052 & -0.212 & -0.110 \\
returned in first year & $(0.293)$ & $(0.240)$ & $(0.128)$ & $(0.142)$ & $(0.063)$ \\
Mother Low & 0.216 & $0.260 *$ & 0.142 & 0.053 & 0.089 \\
Education & $(0.156)$ & $(0.121)$ & $(0.068)$ & $(0.302)$ & $(0.138)$ \\
Mother High & 0.412 & 0.416 & -0.023 & 0.456 & 0.083 \\
Education & $(0.365)$ & $(0.219)$ & $(0.173)$ & $(0.493)$ & $(0.531)$ \\
\hline
\end{tabular}

Notes: Number of observations equals $5 .{ }^{*}$ and $* *$ indicate statistical significance at the $10 \%$ and $5 \%$ levels respectively. We report the coefficients (standard errors) for the POST variable described in the text. All results for children aged 48-71 months. 
Figure 1: Time at home in the first year, by birth quarter for 1998-2002 cohorts

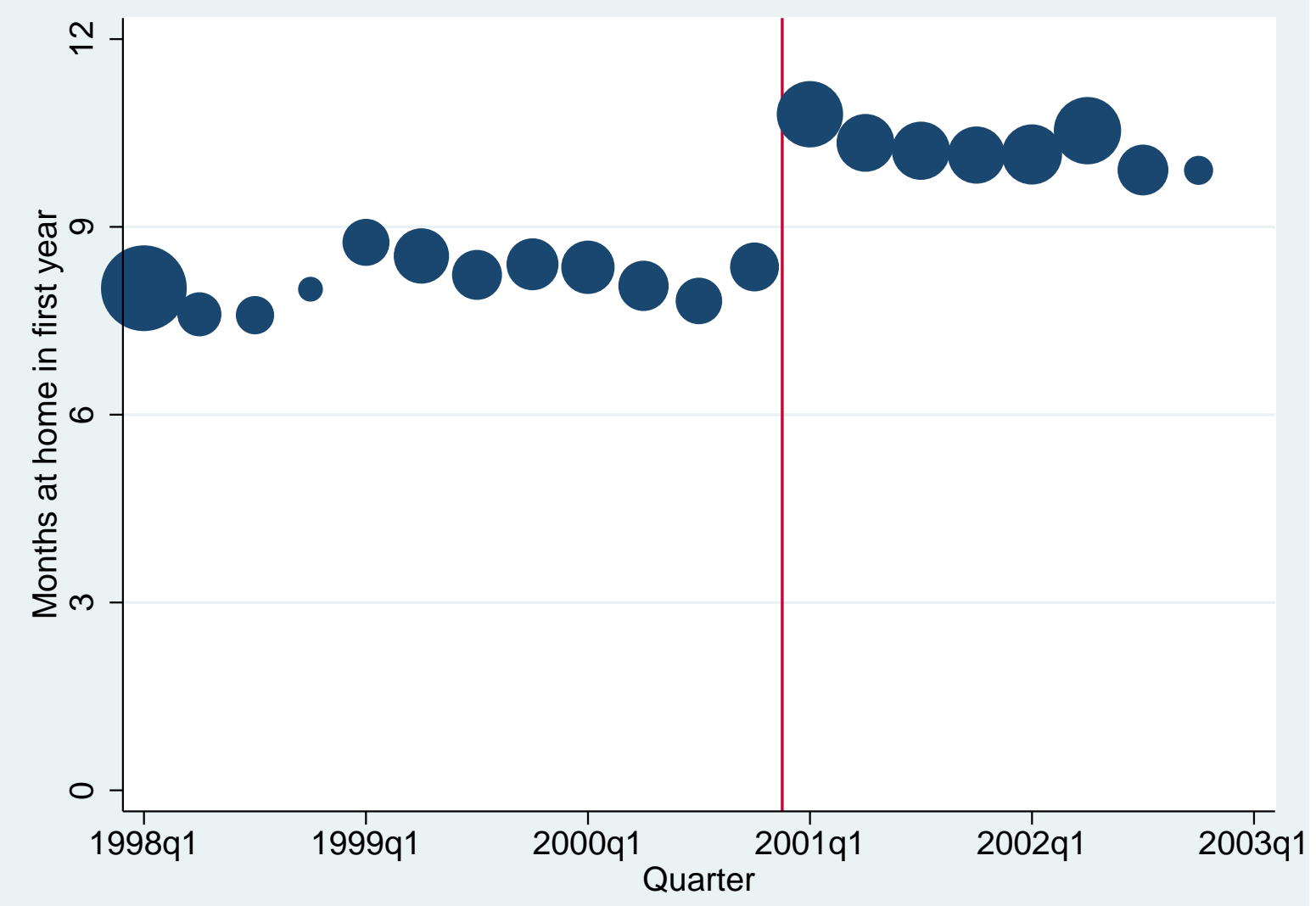

Notes: Data from the NLSCY, using children aged 48-71 months. 
Figure 2a: Standardized PPVT by birth quarter for 1998-2002 cohorts, full axis

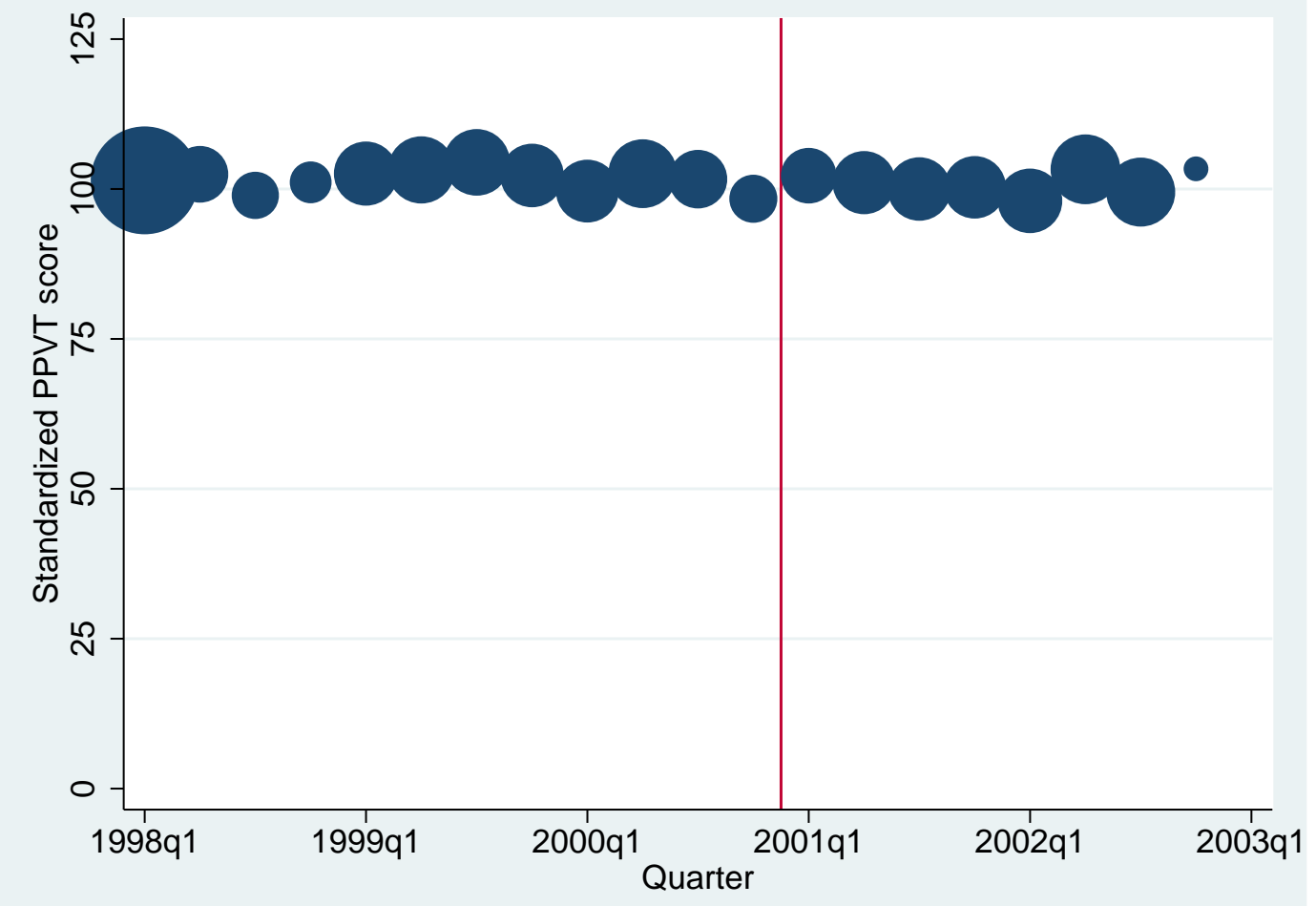

Figure 2b: Standardized PPVT by birth quarter for 1998-2002 cohorts, restricted axis

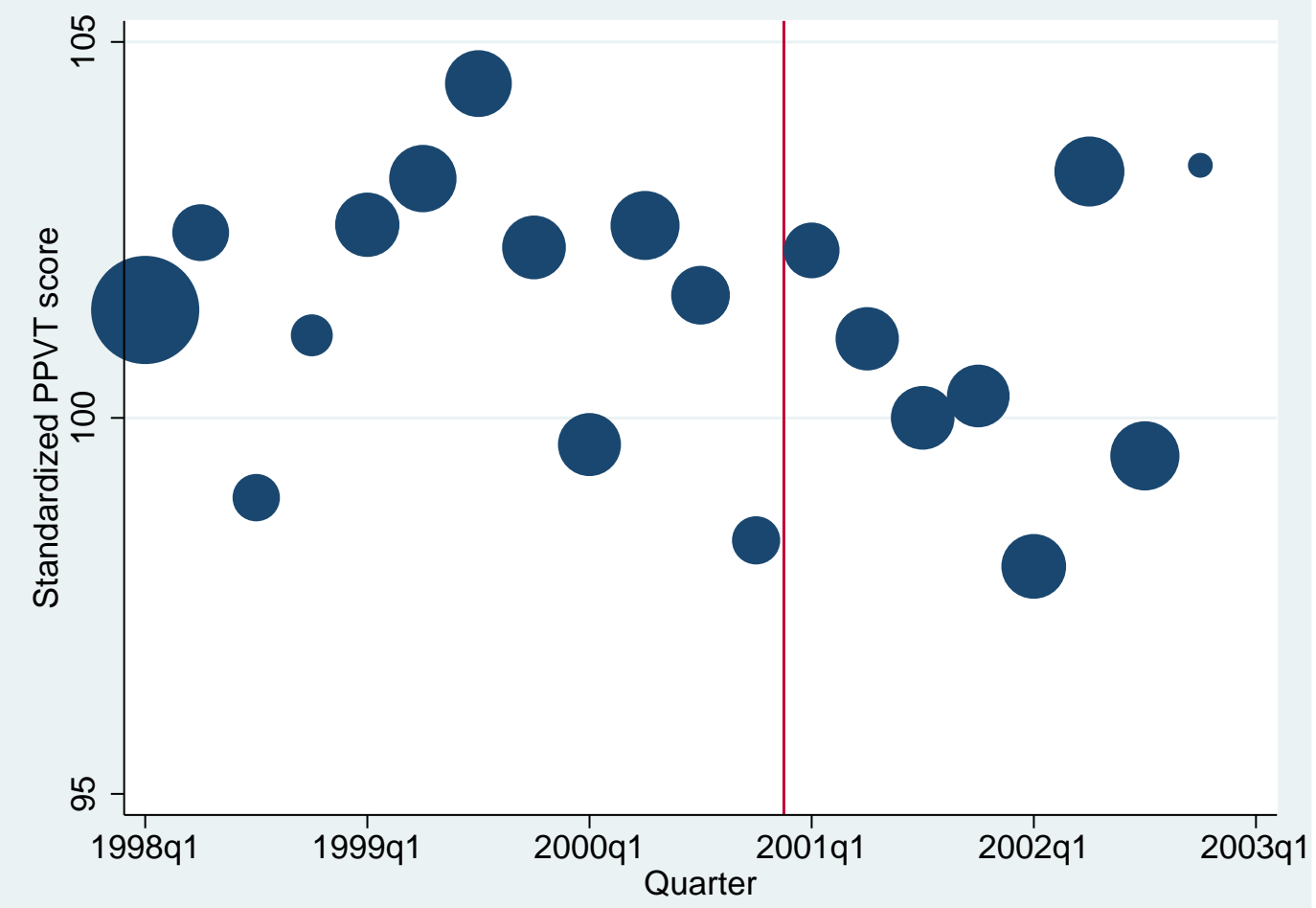

Notes: Data from the NLSCY, using children aged 48-71 months. 
Figure 3a: Estimated birth cohort effects for PPVT Score, 1998-2002 birth cohorts

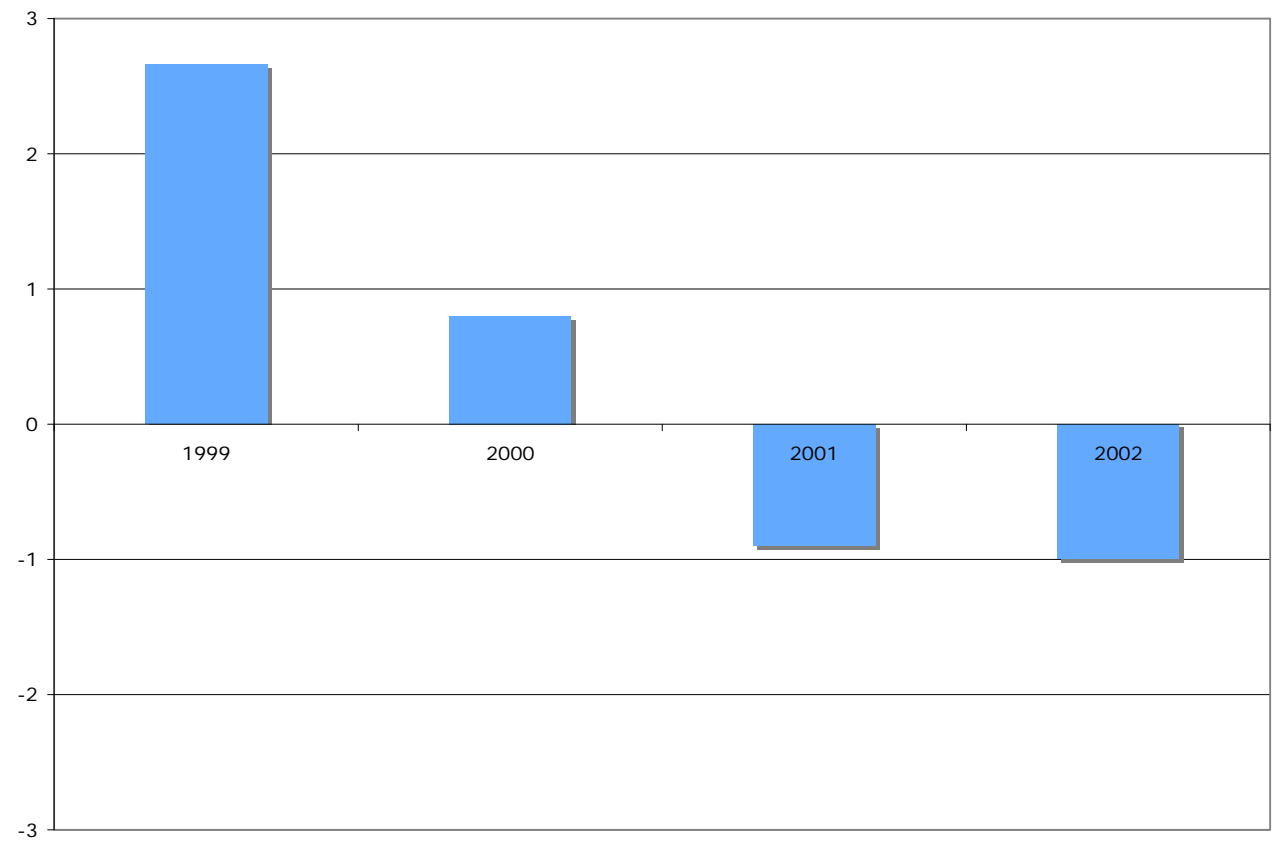

Notes: Estimates are relative to estimate for the 1998 cohort. Observations are for children aged 48-71 months.

Figure 3b: Estimated birth cohort effects for PPVT Score, 1997-2002 birth cohorts

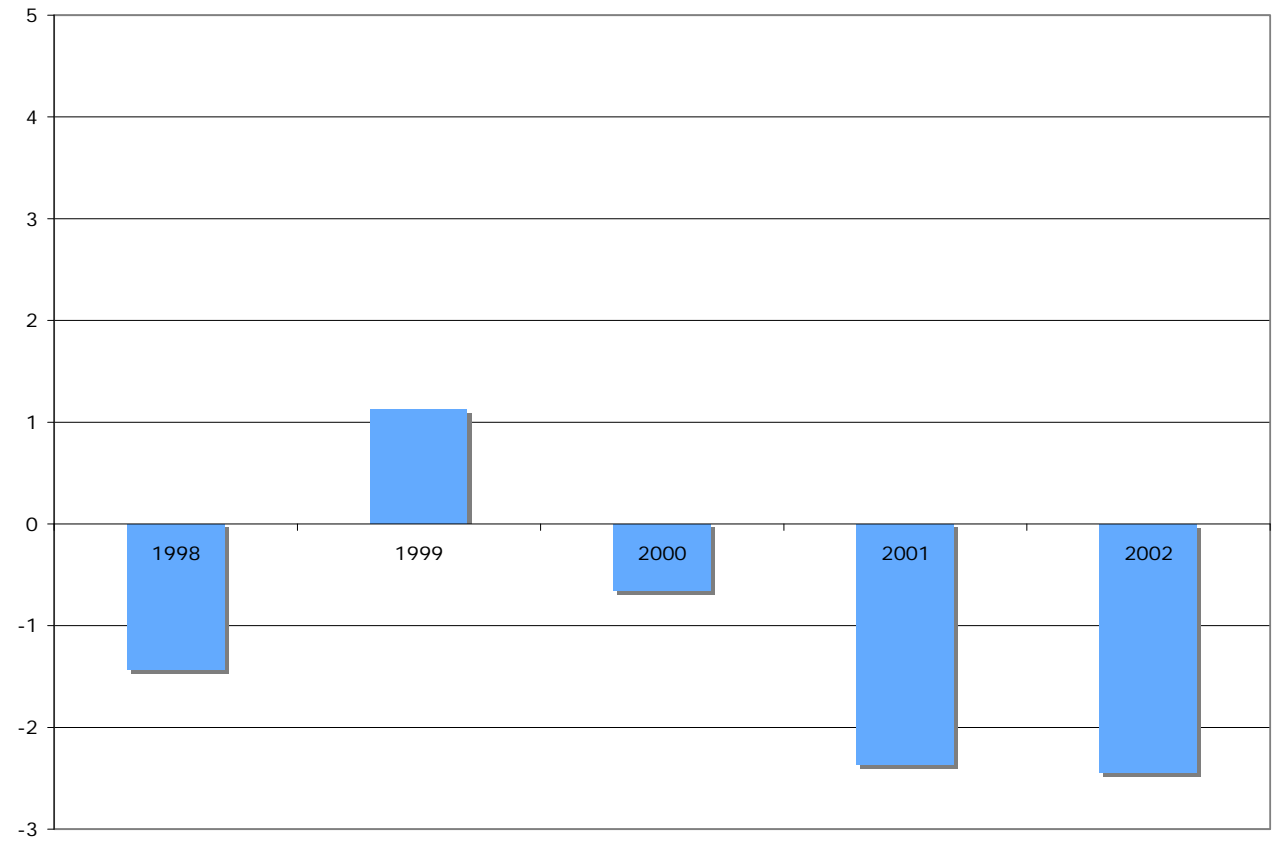

Notes: Estimates are relative to estimate for the 1997 cohort. Observations are for children aged 48-71 months. 
Figure 4: Hyperactivity Score by birth quarter, 1998-2002 birth cohorts

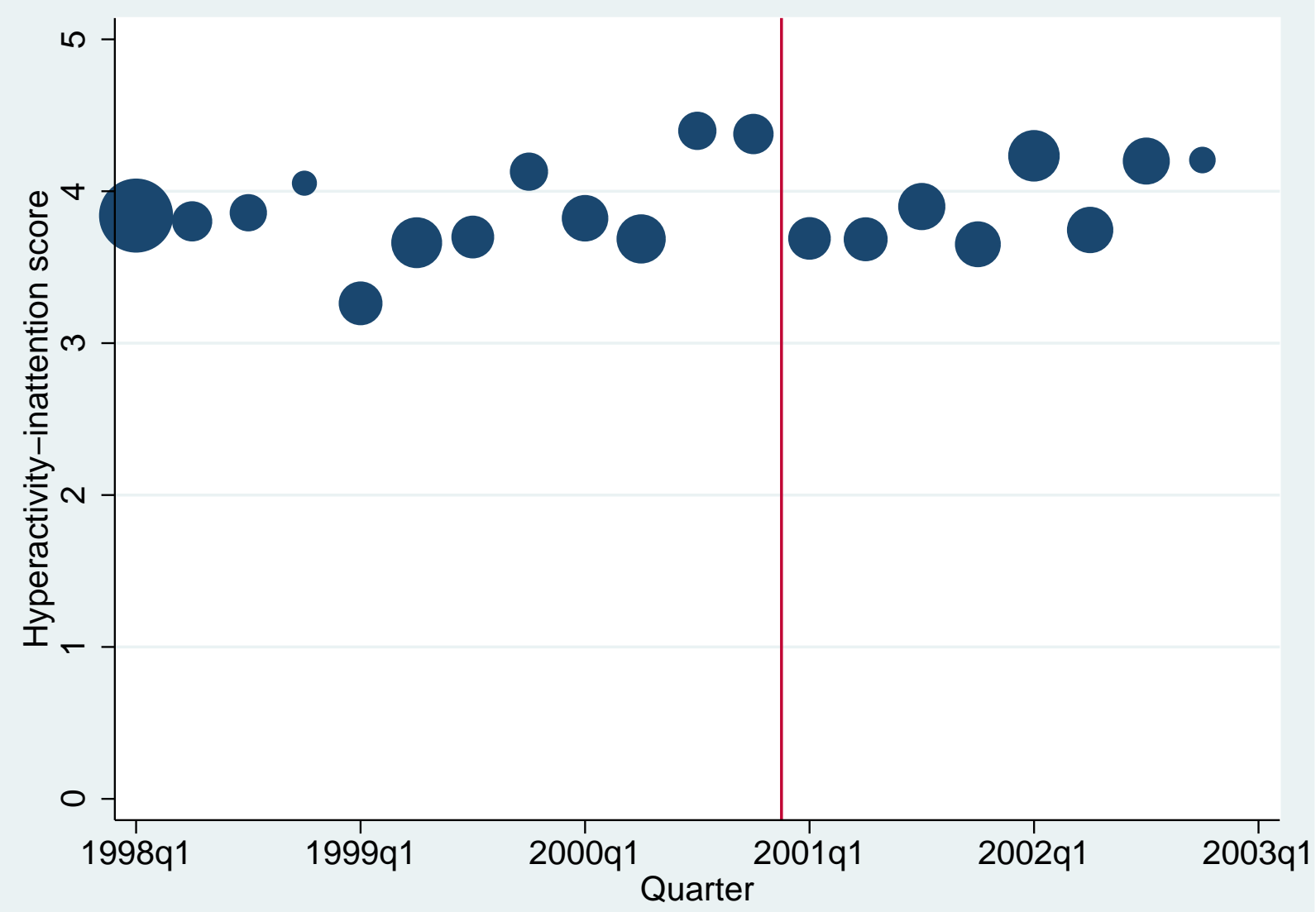

Notes: Data from the NLSCY, using children aged 48-71 months. 
Figure 5: Estimated birth cohort effects for Hyperactivity Score, 1997-2002 birth cohorts

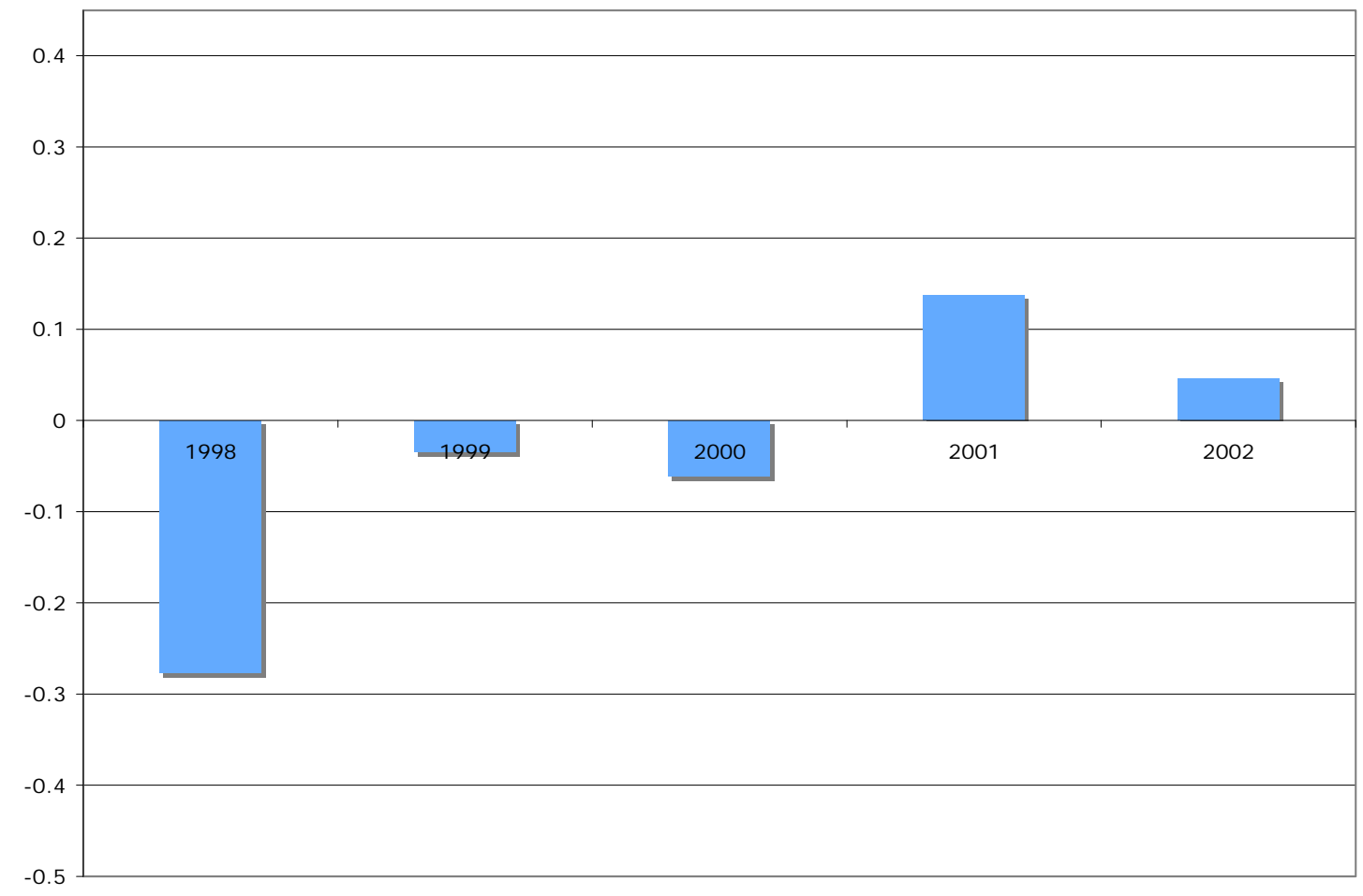

Notes: Estimates are relative to estimate for the 1997 cohort. Observations are for children aged 48-71 months. 
Figure 6: Absolute percentage increase of breastfeeding at selected durations, Kramer et al. (2001) and Baker and Milligan (2008a)

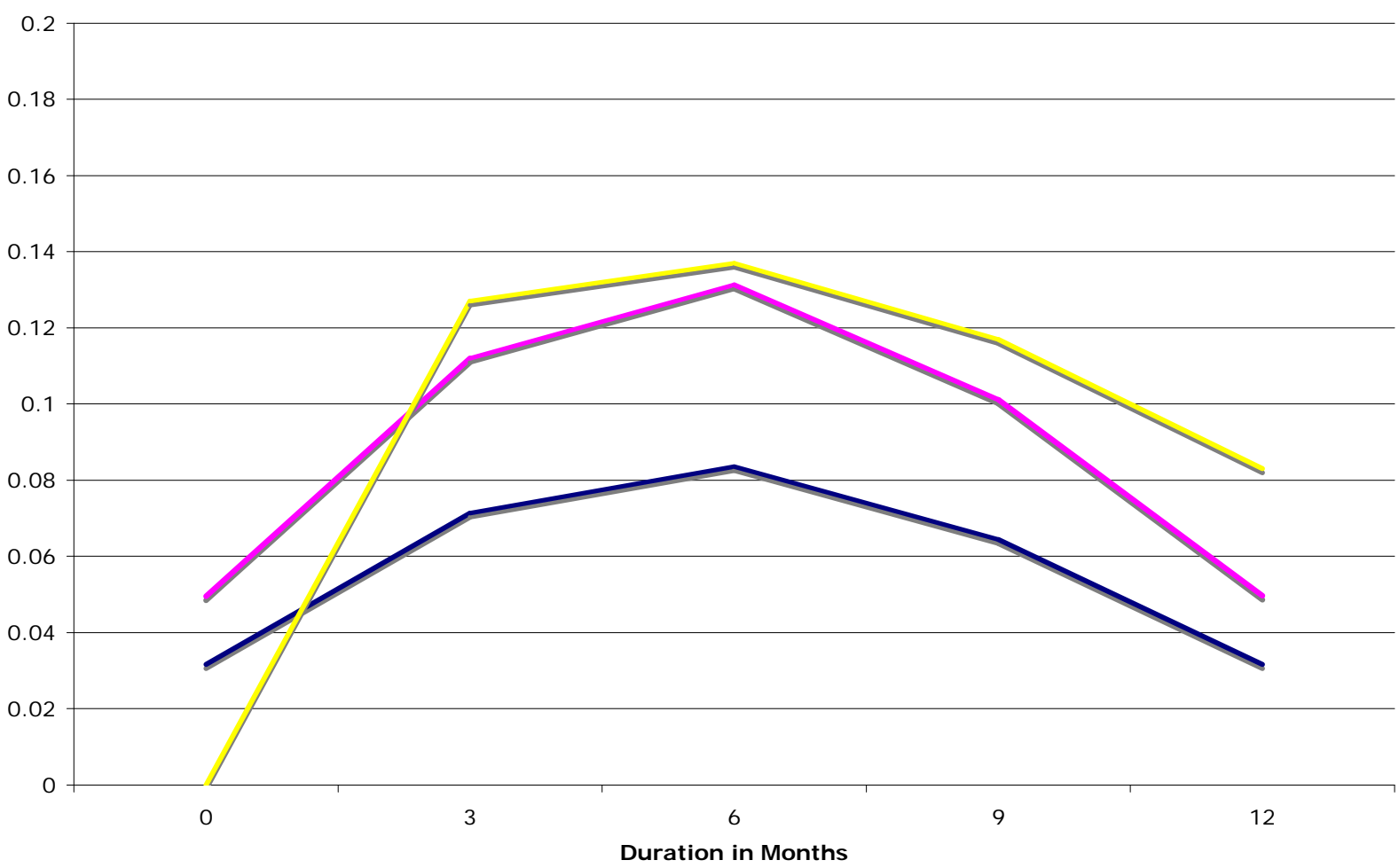

- Baker and Milligan (2008), Intention to Treat

- Baker and Milligan (2008), Treatment on the Treated

Kramer et al. (2008)

Notes: Statistics for Baker and Milligan (2008a) are simple averages of the pre and post-reform probabilities reported in figure 3 of this article. Statistics for Kramer et al. (2001) are taken from table 3 of this study. 


\section{Appendix}

Table A1: Estimated impact of longer maternity leave mandates on observable inputs to childhood development NLSCY

\begin{tabular}{|c|c|c|c|c|c|}
\hline & $\mathrm{N}$ & 1999 & 2000 & 2001 & 2002 \\
\hline \multicolumn{6}{|l|}{ Age 42-71 months } \\
\hline $\begin{array}{l}\text { Time mother home in } \\
\text { first year }\end{array}$ & 5932 & $\begin{array}{c}0.166 \\
(0.279)\end{array}$ & $\begin{array}{c}0.339 \\
(0.227)\end{array}$ & $\begin{array}{c}2.141 \\
(0.269)\end{array}$ & $\begin{array}{c}2.483 \\
(0.210)\end{array}$ \\
\hline $\begin{array}{l}\text { Mother returned to } \\
\text { work post-Birth }\end{array}$ & 5932 & $\begin{array}{l}-0.043 \\
(0.035)\end{array}$ & $\begin{array}{l}-0.038 \\
(0.026)\end{array}$ & $\begin{array}{l}-0.028 \\
(0.034)\end{array}$ & $\begin{array}{l}-0.034 \\
(0.027)\end{array}$ \\
\hline $\begin{array}{l}\text { Continuous work post- } \\
\text { birth }\end{array}$ & 3817 & NA & $\begin{array}{l}-0.031 \\
(0.070)\end{array}$ & $\begin{array}{c}0.022 \\
(0.027)\end{array}$ & $\begin{array}{l}-0.023 \\
(0.069)\end{array}$ \\
\hline Hours at return to work & 3829 & NA & $\begin{array}{c}2.360 \\
(1.977)\end{array}$ & $\begin{array}{c}2.017 \\
(0.883)\end{array}$ & $\begin{array}{c}3.980 \\
((1.920)\end{array}$ \\
\hline $\begin{array}{l}\text { Mother Currently } \\
\text { Employed }\end{array}$ & 5873 & $\begin{array}{l}-0.005 \\
(0.039)\end{array}$ & $\begin{array}{l}-0.025 \\
(0.029)\end{array}$ & $\begin{array}{l}-0.041 \\
(0.039)\end{array}$ & $\begin{array}{l}-0.044 \\
(0.039)\end{array}$ \\
\hline $\begin{array}{l}\text { Mother worked } 20+ \\
\text { hours/week }\end{array}$ & 5872 & $\begin{array}{l}-0.004 \\
(0.040)\end{array}$ & $\begin{array}{l}-0.008 \\
(0.030)\end{array}$ & $\begin{array}{c}0.008 \\
(0.040)\end{array}$ & $\begin{array}{c}0.018 \\
(0.032)\end{array}$ \\
\hline $\begin{array}{l}\text { Child has younger } \\
\text { sibling }(\mathrm{s})\end{array}$ & 5932 & $\begin{array}{l}-0.010 \\
(0.040)\end{array}$ & $\begin{array}{c}0.048 \\
(0.029)\end{array}$ & $\begin{array}{c}0.011 \\
(0.040)\end{array}$ & $\begin{array}{c}0.025 \\
(0.031)\end{array}$ \\
\hline $\begin{array}{l}\text { Child has younger } \\
\text { sibling(s) }\end{array}$ & 5932 & $\begin{array}{l}-0.038 \\
(0.040) \\
\end{array}$ & $\begin{array}{l}-0.030 \\
(0.029)\end{array}$ & $\begin{array}{r}0.017 \\
(0.031) \\
\end{array}$ & $\begin{array}{l}-0066 \\
(0.031)\end{array}$ \\
\hline \multicolumn{6}{|l|}{ Age 13-24 months } \\
\hline $\begin{array}{l}\text { Time mother home in } \\
\text { first year }\end{array}$ & 3462 & $\begin{array}{c}2.936 \\
(0.319)\end{array}$ & $\begin{array}{c}2.864 \\
(0.310)\end{array}$ & $\begin{array}{c}4.864 \\
(0.308)\end{array}$ & $\begin{array}{c}4.575 \\
(0.295)\end{array}$ \\
\hline $\begin{array}{l}\text { Mother returned to } \\
\text { work post-Birth }\end{array}$ & 3462 & $\begin{array}{l}-0.093 \\
(0.041)\end{array}$ & $\begin{array}{l}-0.065 \\
(0.038)\end{array}$ & $\begin{array}{l}-0.104 \\
(0.039)\end{array}$ & $\begin{array}{l}-0.057 \\
(0.039)\end{array}$ \\
\hline $\begin{array}{l}\text { Continuous work post- } \\
\text { birth }\end{array}$ & 2245 & $\begin{array}{c}0.002 \\
(0.040)\end{array}$ & $\begin{array}{l}-0.027 \\
(0.031)\end{array}$ & $\begin{array}{c}0.014 \\
(0.034)\end{array}$ & $\begin{array}{c}0.004 \\
(0.028)\end{array}$ \\
\hline Hours at return to work & 2245 & $\begin{array}{l}-0.393 \\
(1.216)\end{array}$ & $\begin{array}{c}0.186 \\
(1.087)\end{array}$ & $\begin{array}{c}1.995 \\
(1.170)\end{array}$ & $\begin{array}{c}0.839 \\
(1.319)\end{array}$ \\
\hline $\begin{array}{l}\text { Mother Currently } \\
\text { Employed }\end{array}$ & 3458 & $\begin{array}{l}-0.046 \\
(0.039)\end{array}$ & $\begin{array}{l}-0.034 \\
(0.038)\end{array}$ & $\begin{array}{l}-0.058 \\
(0.038)\end{array}$ & $\begin{array}{l}-0.062 \\
(0.038)\end{array}$ \\
\hline $\begin{array}{l}\text { Mother worked 20+ } \\
\text { hours/week }\end{array}$ & 3452 & $\begin{array}{l}-0.066 \\
(0.041)\end{array}$ & $\begin{array}{l}-0.028 \\
(0.039)\end{array}$ & $\begin{array}{l}-0.050 \\
(0.040)\end{array}$ & $\begin{array}{l}-0.057 \\
(0.040)\end{array}$ \\
\hline $\begin{array}{l}\text { Child has younger } \\
\text { sibling(s) }\end{array}$ & 3462 & $\begin{array}{c}0.010 \\
(0.023)\end{array}$ & $\begin{array}{c}0.022 \\
(0.021)\end{array}$ & $\begin{array}{l}-0.004 \\
(0.024)\end{array}$ & $\begin{array}{c}0.002 \\
(0.020)\end{array}$ \\
\hline $\begin{array}{l}\text { Child has older } \\
\text { sibling(s) }\end{array}$ & 3462 & $\begin{array}{c}0.078 \\
(0.041)\end{array}$ & $\begin{array}{c}0.078 \\
(0.035)\end{array}$ & $\begin{array}{c}0.115 \\
(0.039)\end{array}$ & $\begin{array}{l}-0.029 \\
(0.039)\end{array}$ \\
\hline Child in care & 3440 & $\begin{array}{l}-0.016 \\
(0.040)\end{array}$ & $\begin{array}{l}-0.020 \\
(0.039)\end{array}$ & $\begin{array}{l}-0.020 \\
(0.040)\end{array}$ & $\begin{array}{l}-0.001 \\
(0.038)\end{array}$ \\
\hline \multicolumn{6}{|l|}{ Age 25-39 months } \\
\hline $\begin{array}{l}\text { Time mother home in } \\
\text { first year }\end{array}$ & 4746 & $\begin{array}{c}1.855 \\
(0.253)\end{array}$ & $\begin{array}{c}1.700 \\
(0.214)\end{array}$ & $\begin{array}{c}3.788 \\
(0.278)\end{array}$ & $\begin{array}{c}3.693 \\
(0.217)\end{array}$ \\
\hline Mother returned to & 4746 & -0.107 & 0.009 & -0.065 & 0.005 \\
\hline
\end{tabular}




\begin{tabular}{lccccc} 
work post-Birth & & $(0.031)$ & $(0.027)$ & $(0.037)$ & $(0.028)$ \\
Continuous work post- & 2855 & -0.045 & -0.106 & 0.019 & -0.001 \\
birth & & $(0.035)$ & $(0.040)$ & $(0.040)$ & $(0.024)$ \\
Hours at return to work & 2855 & 1.627 & 2.210 & 1.494 & 1.640 \\
& & $(1.148)$ & $(1.550)$ & $(1.421)$ & $(0.917)$ \\
Mother Currently & \multirow{2}{*}{4699} & -0.081 & 0.008 & -0.083 & -0.004 \\
Employed & & $(0.032)$ & $(0.027)$ & $(0.037)$ & $(0.029)$ \\
Mother worked 20+ & \multirow{2}{*}{4705} & -0.053 & 0.029 & -0.038 & 0.014 \\
hours/week & & $(0.033)$ & $(0.028)$ & $(0.037)$ & $(0.030)$ \\
Child has younger & \multirow{2}{*}{4746} & 0.009 & -0.005 & 0.026 & 0.013 \\
sibling(s) & & $(0.030)$ & $(0.023)$ & $(0.037)$ & $(0.026)$ \\
Child has older & \multirow{2}{*}{4746} & -0.020 & -0.001 & -0.007 & -0.064 \\
sibling(s) & & $(0.032)$ & $(0.026)$ & $(0.026)$ & $(0.030)$ \\
Child in care & \multirow{2}{*}{4650} & -0.015 & 0.068 & -0.027 & 0.010 \\
& & $(0.032)$ & $(0.028)$ & $(0.036)$ & $(0.030)$
\end{tabular}

Notes: Each row presents analysis of the indicated dependent variable. Reported are the regression coefficients on the $\gamma^{t}$ year effects from equation (1), with $t=1998$ as the excluded variable. Robust standard errors are in parentheses. 
Table A2: Estimated impact of longer maternity leave mandates on observable inputs to childhood development (LFS, Wage Deflator)

\begin{tabular}{lcccc}
\hline & $\begin{array}{c}\text { Age 60-71 } \\
\text { Months }\end{array}$ & $\begin{array}{c}\text { Age 48-59 } \\
\text { Months }\end{array}$ & $\begin{array}{c}\text { Age 36-47 } \\
\text { Months }\end{array}$ & $\begin{array}{c}\text { Age 13-35 } \\
\text { Months }\end{array}$ \\
\hline Mother's Real Weekly & 17.946 & -4.068 & -13.715 & -7.527 \\
Earnings & $(6.475)$ & $(20.794)$ & $(24.912)$ & $(9.744)$ \\
Mother's Real Hourly & 0.297 & -0.380 & $-1.099 *$ & -0.200 \\
Earnings & $(0.256)$ & $(0.422)$ & $(0.464)$ & $(0.232)$ \\
Economic Family's Real & $43.815^{*}$ & 5.669 & -1.913 & -3.936 \\
Weekly Earnings & $(15.265)$ & $(15.554)$ & $(12.824)$ & $(13.349)$
\end{tabular}

Notes: Number of observations equals 5. $*$ and $* *$ indicate statistical significance at the $10 \%$ and $5 \%$ levels respectively. We report the coefficients (standard errors) for the POST variable described in the text. N.A. not available. 
Table A3: Estimated impact of longer maternity leave mandates on observable inputs to childhood development LFS

\begin{tabular}{|c|c|c|c|c|c|}
\hline & $\mathrm{N}$ & 1999 & 2000 & 2001 & 2002 \\
\hline \multicolumn{6}{|l|}{ Age $13-35$ months } \\
\hline Mother Employed & 8563 & $\begin{array}{l}-0.000 \\
(0.022)\end{array}$ & $\begin{array}{c}0.007 \\
(0.020)\end{array}$ & $\begin{array}{c}0.030 \\
(0.020)\end{array}$ & $\begin{array}{c}0.022 \\
(0.020)\end{array}$ \\
\hline $\begin{array}{l}\text { Mother Employed Full } \\
\text { Time }\end{array}$ & 8563 & $\begin{array}{c}0.015 \\
(0.022)\end{array}$ & $\begin{array}{c}0.013 \\
(0.021)\end{array}$ & $\begin{array}{c}0.029 \\
(0.021)\end{array}$ & $\begin{array}{c}0.047 \\
(0.021)\end{array}$ \\
\hline $\begin{array}{l}\text { Mother's Usual Weekly } \\
\text { Hours }\end{array}$ & 5386 & $\begin{array}{c}0.469 \\
(0.706)\end{array}$ & $\begin{array}{c}0.263 \\
(0.622)\end{array}$ & $\begin{array}{c}0.097 \\
(0.639)\end{array}$ & $\begin{array}{c}0.919 \\
(0.649)\end{array}$ \\
\hline $\begin{array}{l}\text { Mother Not in the } \\
\text { Labor Force }\end{array}$ & 8563 & $\begin{array}{c}0.004 \\
(0.022)\end{array}$ & $\begin{array}{l}-0.016 \\
(0.020)\end{array}$ & $\begin{array}{l}-0.032 \\
(0.020)\end{array}$ & $\begin{array}{l}-0.030 \\
(0.020)\end{array}$ \\
\hline $\begin{array}{l}\text { Mother's Real Weekly } \\
\text { Earnings }\end{array}$ & 4577 & $\begin{array}{c}21.719 \\
(19.176)\end{array}$ & $\begin{array}{c}36.411 \\
(20.926)\end{array}$ & $\begin{array}{c}7.052 \\
(19.537)\end{array}$ & $\begin{array}{c}0.483 \\
(18.771)\end{array}$ \\
\hline $\begin{array}{l}\text { Mother's Real Hourly } \\
\text { Earnings }\end{array}$ & 4577 & $\begin{array}{c}0.765 \\
(0.476)\end{array}$ & $\begin{array}{c}0.831 \\
(0.466)\end{array}$ & $\begin{array}{c}0.194 \\
(0.471)\end{array}$ & $\begin{array}{l}-0.105 \\
(0.440)\end{array}$ \\
\hline $\begin{array}{l}\text { Economic Family's } \\
\text { Real Weekly Earnings }\end{array}$ & 7149 & $\begin{array}{c}32.489 \\
(31.052)\end{array}$ & $\begin{array}{l}11.113 \\
(29.424)\end{array}$ & $\begin{array}{c}30.639 \\
(27.690)\end{array}$ & $\begin{array}{c}0.925 \\
(28.080)\end{array}$ \\
\hline $\begin{array}{l}\text { Mother working PT to } \\
\text { care for own children }\end{array}$ & 8563 & $\begin{array}{l}-0.014 \\
(0.015)\end{array}$ & $\begin{array}{l}-0.000 \\
(0.014)\end{array}$ & $\begin{array}{c}0.012 \\
(0.015)\end{array}$ & $\begin{array}{l}-0.007 \\
(0.015)\end{array}$ \\
\hline $\begin{array}{l}\text { Mother not available for } \\
\text { work-caring for own } \\
\text { children }\end{array}$ & 8563 & $\begin{array}{l}-0.001 \\
(0.001)\end{array}$ & $\begin{array}{c}0.009 \\
(0.005)\end{array}$ & $\begin{array}{c}0.003 \\
(0.002)\end{array}$ & $\begin{array}{c}0.002 \\
(0.002)\end{array}$ \\
\hline $\begin{array}{l}\text { Mother not looking for } \\
\text { work-caring for own } \\
\text { children }\end{array}$ & 8563 & $\begin{array}{l}-0.001 \\
(0.006)\end{array}$ & $\begin{array}{l}-0.002 \\
(0.005)\end{array}$ & $\begin{array}{c}0.004 \\
(0.005)\end{array}$ & $\begin{array}{l}-0.008 \\
(0.004)\end{array}$ \\
\hline $\begin{array}{l}\text { Mother has younger } \\
\text { children }\end{array}$ & 8563 & $\begin{array}{c}0.003 \\
(0.013)\end{array}$ & $\begin{array}{c}0.024 \\
(0.013)\end{array}$ & $\begin{array}{c}0.014 \\
(0.013)\end{array}$ & $\begin{array}{c}0.019 \\
(0.013)\end{array}$ \\
\hline $\begin{array}{l}\text { Mother has older } \\
\text { children }\end{array}$ & 8563 & $\begin{array}{l}-0.015 \\
(0.022)\end{array}$ & $\begin{array}{l}-0.046 \\
(0.020)\end{array}$ & $\begin{array}{l}-0.030 \\
(0.021)\end{array}$ & $\begin{array}{l}-0.007 \\
(0.020)\end{array}$ \\
\hline $\begin{array}{l}\text { Stay at Home Mother } \\
\text { (YBB) }\end{array}$ & 8563 & $\begin{array}{l}-0.009 \\
(0.017)\end{array}$ & $\begin{array}{c}0.006 \\
(0.016)\end{array}$ & $\begin{array}{c}0.006 \\
(0.016)\end{array}$ & $\begin{array}{c}0.018 \\
(0.016)\end{array}$ \\
\hline $\begin{array}{l}\text { Stay at Home Mother } \\
\text { (YOB) }\end{array}$ & 8563 & $\begin{array}{l}-0.015 \\
(0.019)\end{array}$ & $\begin{array}{c}0.007 \\
(0.018)\end{array}$ & $\begin{array}{c}0.009 \\
(0.019)\end{array}$ & $\begin{array}{c}0.009 \\
(0.019)\end{array}$ \\
\hline \multicolumn{6}{|l|}{ Age $36-47$ months } \\
\hline Mother Employed & 4738 & $\begin{array}{c}0.035 \\
(0.027)\end{array}$ & $\begin{array}{l}-0.011 \\
(0.028)\end{array}$ & $\begin{array}{c}0.019 \\
(0.027)\end{array}$ & $\begin{array}{c}0.071 \\
(0.027)\end{array}$ \\
\hline $\begin{array}{l}\text { Mother Employed Full } \\
\text { Time }\end{array}$ & 4738 & $\begin{array}{c}0.006 \\
(0.028)\end{array}$ & $\begin{array}{l}-0.006 \\
(0.029)\end{array}$ & $\begin{array}{c}0.023 \\
(0.028)\end{array}$ & $\begin{array}{c}0.090 \\
(0.029)\end{array}$ \\
\hline $\begin{array}{l}\text { Mother's Usual Weekly } \\
\text { Hours }\end{array}$ & 3015 & $\begin{array}{l}-1.248 \\
(0.868)\end{array}$ & $\begin{array}{l}-0.903 \\
(0.875)\end{array}$ & $\begin{array}{c}0.115 \\
(0.863)\end{array}$ & $\begin{array}{c}0.716 \\
(0.806)\end{array}$ \\
\hline $\begin{array}{l}\text { Mother Not in the } \\
\text { Labor Force }\end{array}$ & 4738 & $\begin{array}{l}-0.059 \\
(0.026)\end{array}$ & $\begin{array}{l}-0.005 \\
(0.028)\end{array}$ & $\begin{array}{l}-0.020 \\
(0.027)\end{array}$ & $\begin{array}{l}-0.073 \\
(0.027)\end{array}$ \\
\hline $\begin{array}{l}\text { Mother's Real Weekly } \\
\text { Earnings }\end{array}$ & 2567 & $\begin{array}{l}-3.426 \\
(26.673)\end{array}$ & $\begin{array}{c}5.333 \\
(26.853)\end{array}$ & $\begin{array}{l}-27.511 \\
(25.520)\end{array}$ & $\begin{array}{c}31.529 \\
(27.506)\end{array}$ \\
\hline
\end{tabular}




\begin{tabular}{|c|c|c|c|c|c|}
\hline $\begin{array}{l}\text { Mother's Real Hourly } \\
\text { Earnings }\end{array}$ & 2567 & $\begin{array}{l}-0.076 \\
(0.631)\end{array}$ & $\begin{array}{c}0.019 \\
(0.640)\end{array}$ & $\begin{array}{l}-1.245 \\
(0.578)\end{array}$ & $\begin{array}{l}-0.112 \\
(0.646)\end{array}$ \\
\hline Economic Family’s & 3991 & 4.315 & -25.299 & 15.149 & 23.740 \\
\hline Real Weekly Earnings & & $(39.185)$ & $(29.717)$ & $(38.778)$ & $(40.625)$ \\
\hline $\begin{array}{l}\text { Mother working PT to } \\
\text { care for own children }\end{array}$ & 4738 & $\begin{array}{c}0.006 \\
(0.020)\end{array}$ & $\begin{array}{c}0.006 \\
(0.021)\end{array}$ & $\begin{array}{l}-0.020 \\
(0.020)\end{array}$ & $\begin{array}{l}-0.044 \\
(0.019)\end{array}$ \\
\hline $\begin{array}{l}\text { Mother not available for } \\
\text { work-caring for own } \\
\text { children }\end{array}$ & 4738 & $\begin{array}{c}0.003 \\
(0.006)\end{array}$ & $\begin{array}{l}-0.004 \\
(0.003)\end{array}$ & $\begin{array}{l}-0.004 \\
(0.003)\end{array}$ & $\begin{array}{l}-0.003 \\
(0.003)\end{array}$ \\
\hline $\begin{array}{l}\text { Mother not looking for } \\
\text { work-caring for own } \\
\text { children }\end{array}$ & 4738 & $\begin{array}{l}-0.008 \\
(0.005)\end{array}$ & $\begin{array}{l}-0.008 \\
(0.005)\end{array}$ & $\begin{array}{l}-0.011 \\
(0.005)\end{array}$ & $\begin{array}{l}-0.003 \\
(0.006)\end{array}$ \\
\hline $\begin{array}{l}\text { Mother has younger } \\
\text { children }\end{array}$ & 4738 & $\begin{array}{c}0.022 \\
(0.026)\end{array}$ & $\begin{array}{c}0.016 \\
(0.027)\end{array}$ & $\begin{array}{c}0.039 \\
(0.027)\end{array}$ & $\begin{array}{c}0.047 \\
(0.027)\end{array}$ \\
\hline $\begin{array}{l}\text { Mother has older } \\
\text { children }\end{array}$ & 4738 & $\begin{array}{l}-0.022 \\
(0.028)\end{array}$ & $\begin{array}{l}-0.012 \\
(0.028)\end{array}$ & $\begin{array}{l}-0.019 \\
(0.027)\end{array}$ & $\begin{array}{l}-0.010 \\
(0.028)\end{array}$ \\
\hline $\begin{array}{l}\text { Stay at Home Mother } \\
\text { (YBB) }\end{array}$ & 4738 & $\begin{array}{c}0.001 \\
(0.017)\end{array}$ & $\begin{array}{c}0.050 \\
(0.020)\end{array}$ & $\begin{array}{c}0.011 \\
(0.017)\end{array}$ & $\begin{array}{c}0.004 \\
(0.018)\end{array}$ \\
\hline $\begin{array}{l}\text { Stay at Home Mother } \\
\text { (YOB) }\end{array}$ & 4738 & $\begin{array}{l}-0.020 \\
(0.020)\end{array}$ & $\begin{array}{c}0.041 \\
(0.023)\end{array}$ & $\begin{array}{c}0.014 \\
(0.022)\end{array}$ & $\begin{array}{l}-0.013 \\
(0.021)\end{array}$ \\
\hline \multicolumn{6}{|l|}{ Age 48-59 months } \\
\hline Mother Employed & 4596 & $\begin{array}{l}-0.029 \\
(0.028)\end{array}$ & $\begin{array}{l}-0.004 \\
(0.028)\end{array}$ & $\begin{array}{l}-0.022 \\
(0.028)\end{array}$ & $\begin{array}{c}0.023 \\
(0.028)\end{array}$ \\
\hline $\begin{array}{l}\text { Mother Employed Full } \\
\text { Time }\end{array}$ & 4596 & $\begin{array}{c}0.006 \\
(0.030)\end{array}$ & $\begin{array}{c}0.021 \\
(0.029)\end{array}$ & $\begin{array}{c}0.009 \\
(0.029)\end{array}$ & $\begin{array}{c}0.053 \\
(0.030)\end{array}$ \\
\hline $\begin{array}{l}\text { Mother's Usual Weekly } \\
\text { Hours }\end{array}$ & 3009 & $\begin{array}{c}0.855 \\
(0.777)\end{array}$ & $\begin{array}{c}1.403 \\
(0.764)\end{array}$ & $\begin{array}{c}1.022 \\
(0.768)\end{array}$ & $\begin{array}{c}1.463 \\
(0.783)\end{array}$ \\
\hline $\begin{array}{l}\text { Mother Not in the } \\
\text { Labor Force }\end{array}$ & 4596 & $\begin{array}{c}0.027 \\
(0.027)\end{array}$ & $\begin{array}{c}0.005 \\
(0.027)\end{array}$ & $\begin{array}{c}0.028 \\
(0.027)\end{array}$ & $\begin{array}{l}-0.009 \\
(0.027)\end{array}$ \\
\hline $\begin{array}{l}\text { Mother's Real Weekly } \\
\text { Earnings }\end{array}$ & 2516 & $\begin{array}{c}44.246 \\
(25.610)\end{array}$ & $\begin{array}{c}9.974 \\
(23.865)\end{array}$ & $\begin{array}{c}8.457 \\
(23.965)\end{array}$ & $\begin{array}{r}54.022 \\
(27.052)\end{array}$ \\
\hline $\begin{array}{l}\text { Mother's Real Hourly } \\
\text { Earnings }\end{array}$ & 2516 & $\begin{array}{c}0.767 \\
(0.617)\end{array}$ & $\begin{array}{c}0.034 \\
(0.598)\end{array}$ & $\begin{array}{l}-0.101 \\
(0.590)\end{array}$ & $\begin{array}{c}0.914 \\
(0.654)\end{array}$ \\
\hline $\begin{array}{l}\text { Economic Family's } \\
\text { Real Weekly Earnings }\end{array}$ & 3827 & $\begin{array}{l}23.473 \\
(41.325)\end{array}$ & $\begin{array}{c}28.440 \\
(41.232)\end{array}$ & $\begin{array}{c}61.332 \\
(41.322)\end{array}$ & $\begin{array}{c}52.328 \\
(43.569)\end{array}$ \\
\hline $\begin{array}{l}\text { Mother working PT to } \\
\text { care for own children }\end{array}$ & 4596 & $\begin{array}{l}-0.022 \\
(0.020)\end{array}$ & $\begin{array}{l}-0.023 \\
(0.020)\end{array}$ & $\begin{array}{l}-0.007 \\
(0.021)\end{array}$ & $\begin{array}{l}-0.020 \\
(0.020)\end{array}$ \\
\hline $\begin{array}{l}\text { Mother not available for } \\
\text { work-caring for own } \\
\text { children }\end{array}$ & 4596 & $\begin{array}{c}0.007 \\
(0.005)\end{array}$ & $\begin{array}{l}-0.001 \\
(0.001)\end{array}$ & $\begin{array}{c}0.001 \\
(0.001)\end{array}$ & $\begin{array}{c}0.000 \\
(0.001)\end{array}$ \\
\hline $\begin{array}{l}\text { Mother not looking for } \\
\text { work-caring for own } \\
\text { children }\end{array}$ & 4596 & $\begin{array}{c}0.004 \\
(0.008)\end{array}$ & $\begin{array}{l}-0.006 \\
(0.006)\end{array}$ & $\begin{array}{l}-0.004 \\
(0.007)\end{array}$ & $\begin{array}{l}-0.007 \\
(0.006)\end{array}$ \\
\hline $\begin{array}{l}\text { Mother has younger } \\
\text { children }\end{array}$ & 4596 & $\begin{array}{l}-0.001 \\
(0.029) \\
\end{array}$ & $\begin{array}{l}-0.001 \\
(0.028)\end{array}$ & $\begin{array}{l}-0.021 \\
(0.028)\end{array}$ & $\begin{array}{r}0.007 \\
(0.029) \\
\end{array}$ \\
\hline
\end{tabular}




\begin{tabular}{|c|c|c|c|c|c|}
\hline $\begin{array}{l}\text { Mother has older } \\
\text { children }\end{array}$ & 4596 & $\begin{array}{c}0.001 \\
(0.028)\end{array}$ & $\begin{array}{c}0.054 \\
(0.028)\end{array}$ & $\begin{array}{l}-0.006 \\
(0.029)\end{array}$ & $\begin{array}{l}-0.035 \\
(0.029)\end{array}$ \\
\hline $\begin{array}{l}\text { Stay at Home Mother } \\
\text { (YBB) }\end{array}$ & 4596 & $\begin{array}{l}-0.004 \\
(0.017)\end{array}$ & $\begin{array}{l}-0.006 \\
(0.018)\end{array}$ & $\begin{array}{c}0.006 \\
(0.019)\end{array}$ & $\begin{array}{l}-0.008 \\
(0.018)\end{array}$ \\
\hline $\begin{array}{l}\text { Stay at Home Mother } \\
\text { (YOB) }\end{array}$ & 4596 & $\begin{array}{l}-0.006 \\
(0.021)\end{array}$ & $\begin{array}{l}-0.013 \\
(0.020)\end{array}$ & $\begin{array}{c}0.006 \\
(0.022)\end{array}$ & $\begin{array}{l}-0.025 \\
(0.020)\end{array}$ \\
\hline \multicolumn{6}{|l|}{ Age $60-71$ months } \\
\hline Mother Employed & 4600 & $\begin{array}{c}0.032 \\
(0.028)\end{array}$ & $\begin{array}{l}-0.021 \\
(0.028)\end{array}$ & $\begin{array}{c}0.026 \\
(0.027)\end{array}$ & $\begin{array}{c}0.023 \\
(0.028)\end{array}$ \\
\hline $\begin{array}{l}\text { Mother Employed Full } \\
\text { Time }\end{array}$ & 4600 & $\begin{array}{c}0.013 \\
(0.030)\end{array}$ & $\begin{array}{l}-0.034 \\
(0.030)\end{array}$ & $\begin{array}{c}0.017 \\
(0.029)\end{array}$ & $\begin{array}{c}0.024 \\
(0.030)\end{array}$ \\
\hline $\begin{array}{l}\text { Mother's Usual Weekly } \\
\text { Hours }\end{array}$ & 3048 & $\begin{array}{c}0.615 \\
(0.890)\end{array}$ & $\begin{array}{l}-0.506 \\
(0.907)\end{array}$ & $\begin{array}{c}0.741 \\
(0.862)\end{array}$ & $\begin{array}{l}1.621 \\
(0.869)\end{array}$ \\
\hline $\begin{array}{l}\text { Mother Not in the } \\
\text { Labor Force }\end{array}$ & 4600 & $\begin{array}{l}-0.017 \\
(0.026)\end{array}$ & $\begin{array}{c}0.044 \\
(0.028)\end{array}$ & $\begin{array}{l}-0.001 \\
(0.026)\end{array}$ & $\begin{array}{l}-0.005 \\
(0.027)\end{array}$ \\
\hline $\begin{array}{l}\text { Mother's Real Weekly } \\
\text { Earnings }\end{array}$ & 2524 & $\begin{array}{l}-0.493 \\
(25.910)\end{array}$ & $\begin{array}{l}-32.714 \\
(28.003)\end{array}$ & $\begin{array}{c}34.149 \\
(28.935)\end{array}$ & $\begin{array}{c}45.811 \\
(29.422)\end{array}$ \\
\hline $\begin{array}{l}\text { Mother's Real Hourly } \\
\text { Earnings }\end{array}$ & 2524 & $\begin{array}{l}-0.141 \\
(0.615)\end{array}$ & $\begin{array}{l}-0.726 \\
(0.658)\end{array}$ & $\begin{array}{c}1.001 \\
(0.630)\end{array}$ & $\begin{array}{c}0.800 \\
(0.684)\end{array}$ \\
\hline $\begin{array}{l}\text { Economic Family's } \\
\text { Real Weekly Earnings }\end{array}$ & 3831 & $\begin{array}{c}18.571 \\
(40.476)\end{array}$ & $\begin{array}{c}-4.703 \\
(39.173)\end{array}$ & $\begin{array}{c}72.117 \\
(40.819)\end{array}$ & $\begin{array}{l}104.933 \\
(43.146)\end{array}$ \\
\hline $\begin{array}{l}\text { Mother working PT to } \\
\text { care for own children }\end{array}$ & 4600 & $\begin{array}{l}-0.001 \\
(0.021)\end{array}$ & $\begin{array}{c}0.005 \\
(0.021)\end{array}$ & $\begin{array}{c}0.008 \\
(0.020)\end{array}$ & $\begin{array}{l}-0.001 \\
(0.021)\end{array}$ \\
\hline $\begin{array}{l}\text { Mother not available for } \\
\text { work-caring for own } \\
\text { children }\end{array}$ & 4600 & $\begin{array}{l}-0.004 \\
(0.003)\end{array}$ & $\begin{array}{l}-0.002 \\
(0.003)\end{array}$ & $\begin{array}{l}-0.003 \\
(0.003)\end{array}$ & $\begin{array}{l}-0.004 \\
(0.003)\end{array}$ \\
\hline $\begin{array}{l}\text { Mother not looking for } \\
\text { work-caring for own } \\
\text { children }\end{array}$ & 4600 & $\begin{array}{l}-0.002 \\
(0.003)\end{array}$ & $\begin{array}{c}0.004 \\
(0.005)\end{array}$ & $\begin{array}{l}-0.001 \\
(0.004)\end{array}$ & $\begin{array}{c}0.002 \\
(0.005)\end{array}$ \\
\hline $\begin{array}{l}\text { Mother has younger } \\
\text { children }\end{array}$ & 4600 & $\begin{array}{l}-0.019 \\
(0.030)\end{array}$ & $\begin{array}{c}0.008 \\
(0.029)\end{array}$ & $\begin{array}{l}-0.026 \\
(0.028)\end{array}$ & $\begin{array}{l}-0.018 \\
(0.030)\end{array}$ \\
\hline $\begin{array}{l}\text { Mother has older } \\
\text { children }\end{array}$ & 4600 & $\begin{array}{l}-0.007 \\
(0.028)\end{array}$ & $\begin{array}{l}-0.040 \\
(0.029)\end{array}$ & $\begin{array}{l}-0.049 \\
(0.028)\end{array}$ & $\begin{array}{l}-0.098 \\
(0.029)\end{array}$ \\
\hline $\begin{array}{l}\text { Stay at Home Mother } \\
\text { (YBB) }\end{array}$ & 4600 & $\begin{array}{l}-0.002 \\
(0.016)\end{array}$ & $\begin{array}{c}0.009 \\
(0.017)\end{array}$ & $\begin{array}{l}-0.017 \\
(0.015)\end{array}$ & $\begin{array}{l}-0.010 \\
(0.016)\end{array}$ \\
\hline $\begin{array}{l}\text { Stay at Home Mother } \\
\text { (YOB) }\end{array}$ & 4600 & $\begin{array}{l}-0.006 \\
(0.019)\end{array}$ & $\begin{array}{c}0.004 \\
(0.020)\end{array}$ & $\begin{array}{l}-0.009 \\
(0.019)\end{array}$ & $\begin{array}{l}-0.018 \\
(0.019)\end{array}$ \\
\hline
\end{tabular}

Notes: Each row presents analysis of the indicated dependent variable. Reported are the regression coefficients on the $\gamma^{t}$ year effects from equation (1), with $t=1998$ as the excluded variable. Robust standard errors are in parentheses. 
Table A4: Estimated impact of longer maternity leave mandates on children's cognitive development

\begin{tabular}{|c|c|c|c|c|c|}
\hline & $\mathrm{N}$ & 1999 & 2000 & 2001 & 2002 \\
\hline \multicolumn{6}{|l|}{ PPVT } \\
\hline \multirow[t]{2}{*}{ Full Sample } & 5343 & 2.662 & 0.799 & -0.896 & -0.998 \\
\hline & & $(0.791)$ & $(0.803)$ & $(0.848)$ & $(0.937)$ \\
\hline \multirow{4}{*}{$\begin{array}{l}\text { Mother returned in first } \\
\text { year } \\
\text { Males }\end{array}$} & 3679 & 2.921 & 1.074 & -1.255 & -1.393 \\
\hline & & $(0.983)$ & $(0.977)$ & $(1.081)$ & $(1.120)$ \\
\hline & 2697 & 3.156 & 1.720 & -1.485 & -0.521 \\
\hline & & $(1.162)$ & $(1.107)$ & $(1.228)$ & $(1.192)$ \\
\hline \multirow[t]{2}{*}{ Females } & 2646 & 1.948 & -0.392 & -0.535 & -1.478 \\
\hline & & $(1.064)$ & $(1.159)$ & $(1.165)$ & $(1.486)$ \\
\hline \multirow{2}{*}{$\begin{array}{l}\text { Males, mother returned } \\
\text { in first year }\end{array}$} & 1870 & 5.048 & 1.821 & -1.739 & -1.461 \\
\hline & & $(1.421)$ & $(1.294)$ & $(1.523)$ & $(1.429)$ \\
\hline \multirow{2}{*}{$\begin{array}{l}\text { Females, mother } \\
\text { returned in first year }\end{array}$} & 1809 & 0.464 & -0.034 & -0.849 & -1.246 \\
\hline & & $(1.300)$ & $(1.462)$ & $(1.497)$ & $(1.727)$ \\
\hline \multirow[t]{2}{*}{ Mother Low Education } & 1360 & 2.856 & 2.708 & -0.107 & 0.261 \\
\hline & & $(1.570)$ & $(1.581)$ & $(1.642)$ & $(1.861$ \\
\hline \multirow[t]{2}{*}{ Mother High Education } & 3983 & 2.343 & -0.243 & -1.217 & -1.511 \\
\hline & & $(0.899)$ & $(0.908)$ & $(0.990)$ & $(1.078)$ \\
\hline \multicolumn{6}{|l|}{ Who Am I? } \\
\hline \multirow[t]{2}{*}{ Full Sample } & 4958 & 2.683 & 1.395 & 1.283 & -0.552 \\
\hline & & $(0.443)$ & $(0.349)$ & $(0.430)$ & $(0.362)$ \\
\hline \multirow{4}{*}{$\begin{array}{l}\text { Mother returned in first } \\
\text { year } \\
\text { Males }\end{array}$} & 3394 & 2.527 & 0.995 & 1.226 & -0.664 \\
\hline & & $(0.521)$ & $(0.418)$ & $(0.535)$ & $(0.462)$ \\
\hline & 2509 & 2.784 & 0.999 & 1.896 & -1.150 \\
\hline & & $(0.611)$ & $(0.486)$ & $(0.618)$ & $(0.491)$ \\
\hline \multirow[t]{2}{*}{ Females } & 2449 & 2.582 & 1.748 & 0.607 & 0.092 \\
\hline & & $(0.617)$ & $(0.481)$ & $(0.563)$ & $(0.515)$ \\
\hline \multirow{2}{*}{$\begin{array}{l}\text { Males, mother returned } \\
\text { in first year }\end{array}$} & 1727 & 2.836 & 0.883 & 1.786 & -0.976 \\
\hline & & $(0.679)$ & $(0.560)$ & $(0.746)$ & $(0.600)$ \\
\hline \multirow{2}{*}{$\begin{array}{l}\text { Females, mother } \\
\text { returned in first year }\end{array}$} & 1667 & 2.387 & 0.790 & 0.775 & -0.464 \\
\hline & & $(0.767)$ & $(0.592)$ & $(0.741)$ & $(0.666)$ \\
\hline \multirow[t]{2}{*}{ Mother Low Education } & 1253 & 2.454 & -0.152 & 1.502 & -1.804 \\
\hline & & $(0.793)$ & $(0.655)$ & $(0.807)$ & $(0.726)$ \\
\hline \multirow[t]{2}{*}{ Mother High Education } & 3705 & -1.179 & 1.451 & 0.890 & -1.310 \\
\hline & & $(0.489)$ & $(0.363)$ & $(0.615)$ & $(0.608)$ \\
\hline \multicolumn{6}{|l|}{ Know Your Numbers } \\
\hline \multirow[t]{2}{*}{ Full Sample } & 5345 & -0.005 & -0.123 & -0.073 & -0.125 \\
\hline & & $(0.045)$ & $(0.035)$ & $(0.045)$ & $(0.039)$ \\
\hline \multirow{2}{*}{$\begin{array}{l}\text { Mother returned in first } \\
\text { year }\end{array}$} & 3677 & 0.010 & -0.089 & -0.037 & -0.169 \\
\hline & & $(0.041)$ & $(0.041)$ & $(0.058)$ & $(0.049)$ \\
\hline \multirow[t]{2}{*}{ Males } & 2698 & 0.026 & -0.132 & 0.011 & -0.167 \\
\hline & & $(0.063)$ & $(0.049)$ & $(0.064)$ & $(0.056)$ \\
\hline Females & 2647 & -0.042 & -0.119 & -0.153 & -0.084 \\
\hline
\end{tabular}




\begin{tabular}{lccccc} 
& & $(0.060)$ & $(0.051)$ & $(0.061)$ & $(0.055)$ \\
Males, mother returned & \multirow{2}{*}{1867} & 0.093 & -0.128 & 0.048 & -0.233 \\
in first year & & $(0.078)$ & $(0.052)$ & $(0.079)$ & $(0.067)$ \\
Females, mother & \multirow{2}{*}{1810} & -0.046 & -0.064 & -0.100 & -0.115 \\
returned in first year & & $(0.074)$ & $(0.063)$ & $(0.077)$ & $(0.069)$ \\
Mother Low Education & \multirow{2}{*}{1357} & -0.024 & -0.157 & -0.025 & -0.101 \\
& & $(0.080)$ & $(0.064)$ & $(0.087)$ & $(0.082)$ \\
Mother High Education & \multirow{2}{*}{3988} & -0.004 & -0.115 & -0.091 & -0.127 \\
& & $(0.053)$ & $(0.041)$ & $(0.053)$ & $(0.043)$
\end{tabular}

Notes: Each row presents analysis of the indicated dependent variable. Reported are the regression coefficients on the $\gamma^{t}$ year effects from equation (1), with $t=1998$ as the excluded variable. Robust standard errors are in parentheses. 
Table A5: Estimated impact of longer maternity leave mandates on children's behavior

\begin{tabular}{|c|c|c|c|c|c|}
\hline & $\mathrm{N}$ & 1999 & 2000 & 2001 & 2002 \\
\hline \multicolumn{6}{|l|}{ Hyperactivity } \\
\hline Full Sample & 5877 & $\begin{array}{c}0.201 \\
(0.225)\end{array}$ & $\begin{array}{c}0.232 \\
(0.160)\end{array}$ & $\begin{array}{c}0.421 \\
(0.213)\end{array}$ & $\begin{array}{l}0.372 \\
(0.160)\end{array}$ \\
\hline $\begin{array}{l}\text { Mother returned in first } \\
\text { year }\end{array}$ & 4007 & $\begin{array}{l}-0.027 \\
(0.267)\end{array}$ & $\begin{array}{c}0.445 \\
(0.195)\end{array}$ & $\begin{array}{c}0.277 \\
(0.259)\end{array}$ & $\begin{array}{c}0.605 \\
(0.200)\end{array}$ \\
\hline Males & 2969 & $\begin{array}{c}0.209 \\
(0.337)\end{array}$ & $\begin{array}{c}0.286 \\
(0.230)\end{array}$ & $\begin{array}{c}0.514 \\
(0.325)\end{array}$ & $\begin{array}{c}0.451 \\
(0.224)\end{array}$ \\
\hline Females & 2908 & $\begin{array}{c}0.168 \\
(0.293)\end{array}$ & $\begin{array}{c}0.198 \\
(0.222)\end{array}$ & $\begin{array}{c}0.335 \\
(0.270)\end{array}$ & $\begin{array}{c}0.310 \\
(0.228)\end{array}$ \\
\hline $\begin{array}{l}\text { Males, mother returned } \\
\text { in first year }\end{array}$ & 2039 & $\begin{array}{l}-0.165 \\
(0.372)\end{array}$ & $\begin{array}{c}0.445 \\
(0.269)\end{array}$ & $\begin{array}{c}0.249 \\
(0.380)\end{array}$ & $\begin{array}{c}0.739 \\
(0.278)\end{array}$ \\
\hline $\begin{array}{l}\text { Females, mother } \\
\text { returned in first year }\end{array}$ & 1968 & $\begin{array}{c}0.179 \\
(0.380)\end{array}$ & $\begin{array}{c}0.500 \\
(0.279)\end{array}$ & $\begin{array}{c}0.385 \\
(0.346)\end{array}$ & $\begin{array}{c}0.477 \\
(0.289)\end{array}$ \\
\hline Mother Low Education & 1547 & $\begin{array}{c}0.991 \\
(0.423)\end{array}$ & $\begin{array}{c}0.303 \\
(0.332)\end{array}$ & $\begin{array}{c}1.054 \\
(0.395)\end{array}$ & $\begin{array}{c}0.657 \\
(0.357)\end{array}$ \\
\hline Mother High Education & 4330 & $\begin{array}{l}-0.184 \\
(0.266)\end{array}$ & $\begin{array}{c}0.218 \\
(0.180)\end{array}$ & $\begin{array}{c}0.082 \\
(0.253)\end{array}$ & $\begin{array}{c}0.241 \\
(0.178) \\
\end{array}$ \\
\hline \multicolumn{6}{|l|}{ Anxiety } \\
\hline Full Sample & 5892 & $\begin{array}{l}-0.047 \\
(0.168)\end{array}$ & $\begin{array}{c}0.136 \\
(0.113)\end{array}$ & $\begin{array}{l}-0.021 \\
(0.159)\end{array}$ & $\begin{array}{l}-0.201 \\
(0.122)\end{array}$ \\
\hline $\begin{array}{l}\text { Mother returned in first } \\
\text { year }\end{array}$ & 4018 & $\begin{array}{l}-0.035 \\
(0.181)\end{array}$ & $\begin{array}{c}0.129 \\
(0.132)\end{array}$ & $\begin{array}{c}0.132 \\
(0.173)\end{array}$ & $\begin{array}{l}-0.008 \\
(0.131)\end{array}$ \\
\hline Males & 2975 & $\begin{array}{c}0.046 \\
(0.238)\end{array}$ & $\begin{array}{c}0.088 \\
(0.162)\end{array}$ & $\begin{array}{l}-0.071 \\
(0.233)\end{array}$ & $\begin{array}{c}0.015 \\
(0.165)\end{array}$ \\
\hline Females & 2917 & $\begin{array}{l}-0.138 \\
(0.240)\end{array}$ & $\begin{array}{c}0.183 \\
(0.154)\end{array}$ & $\begin{array}{c}0.064 \\
(0.210)\end{array}$ & $\begin{array}{r}0.380 \\
(0.169)\end{array}$ \\
\hline $\begin{array}{l}\text { Males, mother returned } \\
\text { in first year }\end{array}$ & 2041 & $\begin{array}{l}-0.125 \\
(0.223)\end{array}$ & $\begin{array}{c}0.147 \\
(0.188)\end{array}$ & $\begin{array}{c}0.061 \\
(0.235)\end{array}$ & $\begin{array}{l}-0.155 \\
(0.177)\end{array}$ \\
\hline $\begin{array}{l}\text { Females, mother } \\
\text { returned in first year }\end{array}$ & 1977 & $\begin{array}{c}0.093 \\
(0.273)\end{array}$ & $\begin{array}{c}0.120 \\
(0.184)\end{array}$ & $\begin{array}{c}0.272 \\
(0.242)\end{array}$ & $\begin{array}{c}0.150 \\
(0.189)\end{array}$ \\
\hline Mother Low Education & 1553 & $\begin{array}{c}0.089 \\
(0.320)\end{array}$ & $\begin{array}{c}0.418 \\
(0.206)\end{array}$ & $\begin{array}{c}0.015 \\
(0.332)\end{array}$ & $\begin{array}{c}0.267 \\
(0.217)\end{array}$ \\
\hline Mother High Education & 4339 & $\begin{array}{l}-0.127 \\
(0.185) \\
\end{array}$ & $\begin{array}{c}0.001 \\
(0.132) \\
\end{array}$ & $\begin{array}{l}-0.104 \\
(0.172) \\
\end{array}$ & $\begin{array}{r}0.109 \\
(0.143) \\
\end{array}$ \\
\hline Physical Aggression & & & & & \\
\hline Full Sample & 5894 & $\begin{array}{l}-0.200 \\
(0.182)\end{array}$ & $\begin{array}{c}0.108 \\
(0.116)\end{array}$ & $\begin{array}{l}-0.243 \\
(0.174)\end{array}$ & $\begin{array}{c}0.066 \\
(0.115)\end{array}$ \\
\hline $\begin{array}{l}\text { Mother returned in first } \\
\text { year }\end{array}$ & 4020 & $\begin{array}{l}-0.198 \\
(0.187)\end{array}$ & $\begin{array}{c}0.237 \\
(0.133)\end{array}$ & $\begin{array}{l}-0.230 \\
(0.172)\end{array}$ & $\begin{array}{c}0.105 \\
(0.128)\end{array}$ \\
\hline Males & 2977 & $\begin{array}{l}-0.191 \\
(0.281)\end{array}$ & $\begin{array}{l}-0.016 \\
(0.166)\end{array}$ & $\begin{array}{c}-0.301 \\
(0.272)\end{array}$ & $\begin{array}{r}-0.030 \\
(0.172)\end{array}$ \\
\hline Females & 2917 & $\begin{array}{l}-0.232 \\
(0.240)\end{array}$ & $\begin{array}{c}0.209 \\
(0.158)\end{array}$ & $\begin{array}{l}-0.230 \\
(0.210)\end{array}$ & $\begin{array}{c}0.166 \\
(0.150)\end{array}$ \\
\hline
\end{tabular}




\begin{tabular}{lccccc} 
Males, mother returned & 2043 & -0.208 & -0.026 & -0.427 & -0.156 \\
$\begin{array}{l}\text { in first year } \\
\text { Females, mother }\end{array}$ & \multirow{2}{*}{1977} & -0.272 & $0.175)$ & $(0.208)$ & $(0.180)$ \\
returned in first year & & $(0.306)$ & $(0.188)$ & $(0.278)$ & $(0.185)$ \\
& & & & \\
Mother Low Education & 1553 & -0.384 & 0.340 & -0.461 & 0.505 \\
& & $(0.388)$ & $(0.229)$ & $(0.390)$ & $(0.257)$ \\
Mother High Education & 4341 & -0.099 & 0.016 & -0.148 & -0.120 \\
& & $(0.158)$ & $(0.136)$ & $(0.150)$ & $(0.119)$ \\
\hline Indirect Aggression & & & & & \\
\hline Full Sample & 5775 & -0.237 & 0.121 & -0.171 & 0.103 \\
& & $(0.111)$ & $(0.074)$ & $(0.108)$ & $(0.100)$ \\
Mother returned in first & 3939 & -0.201 & 0.093 & -0.114 & 0.014 \\
year & & $(0.109)$ & $(0.073)$ & $(0.106)$ & $(0.075)$ \\
Males & 2921 & -0.207 & 0.194 & -0.250 & 0.149 \\
& & $(0.166)$ & $(0.114)$ & $(0.161)$ & $(0.168)$ \\
Females & \multirow{2}{*}{2854} & -0.258 & 0.047 & -0.087 & 0.052 \\
& & $(0.140)$ & $(0.094)$ & $(0.129)$ & $(0.088)$ \\
Males, mother returned & 2006 & -0.125 & 0.147 & 0.061 & -0.155 \\
in first year & & $(0.223)$ & $(0.188)$ & $(0.235)$ & $(0.177)$ \\
Females, mother & \multirow{2}{*}{1933} & -0.298 & 0.102 & -0.043 & 0.073 \\
returned in first year & & $(0.176)$ & $(0.117)$ & $(0.172)$ & $(0.113)$ \\
Mother Low Education & \multirow{2}{*}{1524} & -0.598 & 0.136 & -0.601 & 0.436 \\
& & $(0.242)$ & $(0.143)$ & $(0.248)$ & $(0.276)$ \\
Mother High Education & \multirow{2}{*}{4251} & -0.041 & 0.112 & 0.015 & -0.040 \\
& & $(0.096)$ & $(0.088)$ & $(0.092)$ & $(0.062)$ \\
\hline
\end{tabular}

Notes: Each row presents analysis of the indicated dependent variable. Reported are the regression coefficients on the $\gamma^{t}$ year effects from equation (1), with $t=1998$ as the excluded variable. Robust standard errors are in parentheses. 